OPEN ACCESS

Edited by:

Yu Dong,

Curtin University, Australia

Reviewed by:

Azman Hassan,

University of Technology

Malaysia, Malaysia

Oisik Das,

Luleå University of

Technology, Sweden

*Correspondence:

Mustapha Kaci

kacimu@yahoo.fr

Specialty section

This article was submitted to Polymeric and Composite Materials,

a section of the journal

Frontiers in Materials

Received: 16 July 2019 Accepted: 25 November 2019 Published: 17 December 2019

Citation:

Aouat T, Kaci M, Lopez-Cuesta J-M and Devaux E (2019) Investigation on the Durability of PLA

Bionanocomposite Fibers Under Hygrothermal Conditions.

Front. Mater. 6:323.

doi: 10.3389/fmats.2019.00323

\section{Investigation on the Durability of PLA Bionanocomposite Fibers Under Hygrothermal Conditions}

\author{
Tassadit Aouat ${ }^{1,2}$, Mustapha Kaci ${ }^{1 *}$, José-Marie Lopez-Cuesta ${ }^{3}$ and Eric Devaux ${ }^{4}$ \\ 'Laboratoire des Matériaux Polymères Avancés, Faculté de Technologie, Université de Bejaia, Bejaia, Algeria, ${ }^{2}$ Faculté des \\ Sciences et de la Technologie, Université Yahia Farès, Médéa, Algeria, ${ }^{3}$ Centre des Matériaux des Mines d'Alès, IMT Mines \\ Alès, Alès, France, ${ }^{4}$ École Nationale Supérieure des Arts et Industries Textiles, GEMTEX, Roubaix, France
}

Hygrothermal aging of neat poly(lactic acid) (PLA), PLA/microcrystalline cellulose (MCC), and PLA/cellulose nanowhiskers (CNW) fibers prepared by melt-spinning process was investigated at 95\% relative humidity $(\mathrm{RH})$ and two temperatures, i.e., 45 and $60^{\circ} \mathrm{C}$. PLA bionanocomposite fibers were melt compounded at filler content of 1 wt\% in the presence of PLA-grafted-maleic anhydride (PLA-g-MA) (7 wt\%) used as compatibilizer. The influence of the type of cellulosic filler and the temperature on the hydrolytic degradation kinetics was evaluated through changes in molecular structure and physico-mechanical properties of the samples. The study showed, that all exposed fibers to hygrothermal aging, were subjected to chain scission mechanism responsible for the decrease in average molecular weight, thermal stability and tensile properties, however, more pronounced after 14 days at $60^{\circ} \mathrm{C}$. Furthermore, an increase in crystallinity with a fast crystallization process was noticed for all exposed fibers. The study revealed that the hydrolysis rate increased by 5,6 , and 7 times after 14 days at $60^{\circ} \mathrm{C}$ compared to 25 days at $45^{\circ} \mathrm{C}$ for neat PLA, PLA/PLA-g-MA/MCC1, and PLA/PLA-g-MA/CNW1 fibers, respectively. This has been ascribed to the catalytic behavior of the cellulosic fillers which promotes water diffusion into the PLA matrix. Finally, the study concludes to the capacity of PLA fibers to better withdraw to hydrothermal aging in comparison to PLA/cellulose bionanocomposites. The durability of PLA fibers to hygrothermal degradation is established in the following order: PLA > PLA/PLA-g-MA/MCC1 $>$ PLA/PLA-g-MA/CNW1.

Keywords: polylactide, cellulose, bionanocomposites, hygrothermal aging, hydrolysis

\section{INTRODUCTION}

The development of biodegradable and renewable polymeric materials as natural fiber composites is increasing significantly regarding their economic and ecological advantages (Vilaplana et al., 2010). The interest shown in biodegradable polymers meets the concerns of preserving the environment by minimizing the use of generally polluting petrochemical synthetic polymers and also by avoiding dependence on non-renewable resources. In this context, PLA, which belongs to the family of aliphatic polyesters, is one of the main representatives of the biodegradable polymers (Hajba et al., 2015). Moreover, PLA has good mechanical and optical properties, which are comparable to the conventional synthetic polymers, like polyolefin and PET. It is therefore widely used in many 
applications involving food packaging, automotive parts, disposable tableware, sutures and drug delivery device (Chow et al., 2014). However, expanding the utilization of PLA to other industrial fields is rather limited due to its slow crystallization speed and brittleness to some extent (Sun et al., 2017). To overcome these issues, many studies have shown that adding natural fibers or cellulose nanomaterials is an effective, useful method to reinforce PLA (Mokhena et al., 2018). Cellulose due to its abundant availability, renewability, biodegradability, high strength and stiffness, could replace advantageously layered silicates, carbon nanomaterials and other metallic oxide fillers. According to the literature (Rahman et al., 2014), the theoretical modulus of the native cellulose is estimated at $167.5 \mathrm{GPa}$, which is one of the strongest and stiffest natural fibers available. Cellulose materials as cellulose nanofibers (CNF), cellulose nanowhiskers (CNW), and microcrystalline cellulose (MCC) have a high potential to act as reinforcing agents in biopolymers. However, the highly hydrophilic surface of cellulose makes it difficult to prevent fiber aggregation in hydrophobic polymers, such as PLA (Wang and Drzal, 2012). There are three main approaches available to improve the dispersion and the interface bonding of the cellulosic filler with the polymer matrix, through either polymer or filler modification, or the addition of a third component, i.e., a coupling agent, such as maleic anhydride grafted polymers (Hassaini et al., 2017; Hamad et al., 2018). In the current paper, which is a continuation of a previous work (Aouat et al., 2018), PLA-g-MA was used as the compatibilizer for the PLA/cellulose bionanocomposites to improve the matrix-filler affinity.

Furthermore, the sensitivity to moisture uptake is a wellknown weakness, which limits the performance of biocomposite materials, due to the hydrophilic nature of the biopolymer matrix and/or the natural reinforcement (Vilaplana et al., 2010). Moisture uptake can induce swelling of the biocomposite which may impair interfacial strength and subsequently generate cracks in the matrix (Bayart et al., 2017). Swelling phenomenon is attributed to the interaction of the fiber cell-wall components (containing $-\mathrm{OH},-\mathrm{COOH}$, and other polar groups) with water molecules via hydrogen bond formation (Islam et al., 2010). These are serious issues for long-term applications where the biocomposites may be exposed to the combined effect of high humidity and temperature conditions. Although, a recent publication (Mangin et al., 2018) has shown that incorporating miscible PMMA to flame-retarded PLA improves its resistance to hydrothermal aging, further studies are however necessary to better understanding the behavior of such materials in a high humid atmosphere or in water. This is a prerequisite for any outdoor application. Despite the technological importance of this research theme, few studies are unfortunately available in literature on degradation of PLA/cellulose biocomposite materials in hygrothermal conditions, and even less on melt-spun PLA fibers (Xian et al., 2018).

Therefore, the objective of this paper was to investigate the influence of combined humid atmosphere and temperature on the morphology, the chemical structure and the physical properties of neat PLA, PLA/PLA-g-MA/MCC1, and PLA/PLA$g$-MA/CNW1 bionanocomposite fibers. The hygrothermal aging was conducted in a climatic chamber at $95 \% \mathrm{RH}$ and at two temperatures: 45 and $60^{\circ} \mathrm{C}$. The filler size effect on the rate of hydrolysis of PLA fibers was also investigated. The choice of 45 and $60^{\circ} \mathrm{C}$ as the hygrothermal degradation temperatures was not arbitrary, it was justified by the fact that PLA fibers are in glassy state at $45^{\circ} \mathrm{C}$ and rubbery state at $60^{\circ} \mathrm{C}$, considering that the transition temperature of PLA is around $60^{\circ} \mathrm{C}$. Furthermore, $60^{\circ} \mathrm{C}$ is often the temperature which is used in clearing treatment of textile fibers in the industry.

\section{EXPERIMENTAL}

\section{Materials Used}

PLA was fiber-grade resin $6202 \mathrm{D}$ and supplied by Nature Works LLC. According to the manufacturer, the main physical characteristics of the polymer are as follows: density $=1.24$ $\mathrm{g} / \mathrm{cm}^{3}$, glass transition temperature $\left(\mathrm{T}_{\mathrm{g}}\right)=60^{\circ} \mathrm{C}$, and melting point $\left(\mathrm{T}_{\mathrm{m}}\right) \sim 160-170^{\circ} \mathrm{C}$.

Microcrystalline cellulose (MCC) was supplied by SigmaAldrich under the trade name Avicel PH 101. MCC was also used as the raw material for extracting cellulose nanowhiskers (CNW) by using sulfuric acid hydrolysis in aqueous media (Aouat et al., 2018). Sulfuric acid 95-97\% was purchased from Sigma-Aldrich. PLA-g-MA ( $\sim 3$ wt. $\%$ of maleic anhydride) used as the compatibilizer for the cellulosic PLA fibers, was prepared in the laboratory Materia Nova (Mons, Belgium) by reactive extrusion using a Leistritz twin-screw extruder $(\mathrm{L} / \mathrm{D}=50)$.

\section{Preparation of PLA/Cellulose Bionanocomposites}

PLA and PLA bionanocomposite fibers were manufactured by two-step process. The first one consisted of preparing pellets by a Thermo-Haake co-rotating intermeshing twin-screw extruder $(\mathrm{L} / \mathrm{D}=25)$ according to the compositions reported in Table 1. In the second step, the pellets were used to obtain the multifilament fibers using a melt-spinning machine, Model Spinboy I, manufactured by Busschaert Engineering. Elaboration of PLA fibers has been detailed in a recent paper (Aouat et al., 2018).

TABLE 1 | Values of water uptake at saturation, water diffusion coefficient and activation energy of PLA, PLA/PLA-g-MA/MCC1, and PLA/PLA-g-MA/CNW1 fibers recorded at 45 and $60^{\circ} \mathrm{C}$ in hygrothermal conditions.

\begin{tabular}{|c|c|c|c|c|c|}
\hline \multirow[t]{2}{*}{ Fibers } & \multicolumn{2}{|c|}{$\begin{array}{c}\text { Water uptake at } \\
\text { saturation } \\
(\%)\end{array}$} & \multicolumn{2}{|c|}{$\begin{array}{l}\text { Water diffusion } \\
\text { coefficient } \\
\left(\mathrm{m}^{2} / \mathrm{s}\right)\end{array}$} & \multirow[t]{2}{*}{$\begin{array}{c}\text { Activation } \\
\text { energy } \\
\text { (kcal/mol) }\end{array}$} \\
\hline & $45^{\circ} \mathrm{C}$ & $60^{\circ} \mathrm{C}$ & $45^{\circ} \mathrm{C}$ & $60^{\circ} \mathrm{C}$ & \\
\hline $\begin{array}{l}\text { PLA (100 } \\
\text { wt\%) }\end{array}$ & 0.51 & 1.17 & $2.36 \times 10^{-16}$ & $4.99 \times 10^{-16}$ & 10.5 \\
\hline $\begin{array}{l}\text { PLA/PLA-g- } \\
\text { MA/MCC1 } \\
\text { (92/7/1 wt\%) }\end{array}$ & 1.7 & 1.94 & $4.13 \times 10^{-16}$ & $6.36 \times 10^{-16}$ & 6.08 \\
\hline $\begin{array}{l}\text { PLA/PLA-g- } \\
\text { MA/CNW1 } \\
\text { (92/7/1 wt\%) }\end{array}$ & 1.3 & 1.55 & $3.38 \times 10^{-16}$ & $5.76 \times 10^{-16}$ & 7.48 \\
\hline
\end{tabular}




\section{Hygrothermal Aging}

Both PLA and PLA bionanocomposite fibers in form of coils were subjected to hygrothermal aging in a climatic chamber of Model Excal 2221-HA at 95\% RH and two temperatures, i.e., 45 and $60^{\circ} \mathrm{C}$. The fibers were placed on metal grid in the center of the enclosure having the following dimensions: 50 $\times 50 \times 75 \mathrm{~cm}$. The climatic chamber used is equipped with the Spirale ${ }^{\circledR}$ software, which allows the aging parameters to be controlled. Fiber samples were removed periodically with time for characterization tests.

\section{Technical Characterization Water Uptake}

The moisture uptake of PLA fibers was estimated by weighing. The samples removed from the climatic chamber, were immediately weighed $\left(m_{2}\right)$ to avoid any moisture loss and weighed again after sampling before being replaced in the chamber. Percent moisture uptake $(\% \mathrm{H})$ is determined by Equation (1):

$$
\% \mathrm{H}=\% \mathrm{H}_{1}+\frac{\mathrm{m}_{2}-\mathrm{m}_{1}}{\mathrm{~m}_{2}} .100
$$

Where, $\% \mathrm{H}$ is the percent moisture uptake, $\% \mathrm{H}_{1}$ is the percent moisture uptake at previous removing; $\mathrm{m}_{1}$ is the sample mass at previous removing, while $\mathrm{m}_{2}$ is the sample mass currently noted.

In addition, the water uptake capacity of the exposed PLA and PLA bionanocomposite fibers in the climatic chamber was also expressed in terms of diffusion coefficient. Assuming that the PLA fibers have a cylindrical shape, the water diffusivity in the matrix is expressed by Equation (2) (Hossain et al., 2014):

$$
D=\frac{\pi d^{2}}{16 W_{s}^{2}} \times \frac{\left(W_{2}-W_{1}\right)^{2}}{\left(\sqrt{t_{2}}-\sqrt{t_{1}}\right)^{2}}
$$

Where, $D$ is the water diffusion coefficient in $\left(m^{2} \cdot s^{-1}\right), d$ is the average diameter of the fiber in $(\mathrm{m}), W s$ is the water uptake at saturation in (\%) and $\frac{\left(W_{2}-W_{1}\right)^{2}}{\left(\sqrt{t_{2}}-\sqrt{t_{1}}\right)^{2}}$ is the square slope of the linear portion of the curve of water uptake vs. root of time.

The activation energy of water diffusion $\left(E_{D}\right)$ in $(\mathrm{kcal} / \mathrm{mol})$ was determined by linear regression through $(\ln D)$ vs. $(1 / T)$ according to Arrhenius equation, i.e., Equation (3) (Fayolle and Verdu, 2005):

$$
\ln D=a-\frac{E_{D}}{R T}
$$

Where, $\mathrm{T}$ is temperature in $(\mathrm{K})$ and $\mathrm{R}$, the ideal gas constant $\left(8.32 \mathrm{~kJ} \cdot \mathrm{mol}^{-1} \cdot \mathrm{K}^{-1}\right)$.

\section{Viscosimetric Measurements}

Viscosimetric measurements were carried out in an Ubbelhode viscometer at $30^{\circ} \mathrm{C}$ with chloroform as solvent. Assuming the kinetic energy and shear corrections negligible, the Huggins equation was applied to estimate the intrinsic viscosity [ $\eta]$. The latter is related to the viscosity average molecular weight $\left(\overline{M_{v}}\right)$, by the Mark-Houwink-Sakurada equation: $[\eta]=K \cdot \bar{M}_{\mathrm{v}}^{\mathrm{a}}$ (where, K and a, are empirical constants). For the PLA/chloroform system at $30^{\circ} \mathrm{C}, \mathrm{K}=1.31 \times 10^{-4} \mathrm{dl} / \mathrm{g}$ and $\mathrm{a}=0.759$ (Persson and Mikael, 2013). The extent of hydrolytic degradation of PLA fibers and its bionanocomposites is determined from the number of mainchain scission index (SI). SI is defined according to the following Equation (4) (Remili et al., 2009).

$$
\mathrm{SI}=\left[\bar{M}_{\mathrm{v} 0} / \overline{M_{\mathrm{v}}}\right]-1
$$

Where $\bar{M}_{\mathrm{v} 0}$ and $\overline{M_{\mathrm{v}}}$ are the viscosity-average molecular weight before and after hygrothermal exposure of the fibers. In addition, the hydrolysis rate was also followed by the hydrolysis rate constant $(\mathrm{k})$ determined by the linear regression method.

\section{Tensile Measurements}

The tensile measurements were conducted on twisted fibers ( 80 monofilaments). A mechanical tester system MTS associated with a force sensor of $1 \mathrm{kN}$ was used. In order to adjust the clamp load and to grip the sample with the least amount of stress, a special design for testing yarns was used (capstan grips). Capstan roller in addition to vise action allows the sample to be both clamped at the desired level and to be wound around the capstan to distribute the remaining stress via friction. The tensile properties were measured according to ISO 2062 standard test method. A loading speed of $200 \mathrm{~mm} / \mathrm{min}$ and a distance of $200 \mathrm{~mm}$ between grips were applied. All mechanical tests were carried out by using specimens previously stored for at least $48 \mathrm{~h}$ at $20 \pm 2^{\circ} \mathrm{C}$ at $50 \pm$ $3 \% \mathrm{RH}$. The values were averaged out over five measurements for each sample.

Because of the variation in the fibers fineness, the tensile strength is expressed as tenacity (cN/tex), a specific value related to fineness (force per unit fineness). Fineness in tex $(\mathrm{g} / \mathrm{km})$, was determined by dividing the mass of fibers by their known length (Milanovic et al., 2012).

\section{Differential Scanning Calorimetry (DSC)}

DSC thermograms of PLA fibers were performed using a 2920 Modulated DSC (TA Instruments) before and after exposure to hygrothermal aging. The dried samples of an average weight of about $10 \mathrm{mg}$ were placed in hermetically closed DSC capsules in nitrogen atmosphere at $50 \mathrm{ml} / \mathrm{min}$. The heating and cooling steps were carried out at a rate of $10^{\circ} \mathrm{C} / \mathrm{min}$ from 20 to $200^{\circ} \mathrm{C}$ and from 200 to $20^{\circ} \mathrm{C}$, respectively. Glass transition temperature $\left(\mathrm{T}_{\mathrm{g}}\right)$, cold crystallization temperature $\left(\mathrm{T}_{\mathrm{cc}}\right)$ and melting temperature $\left(\mathrm{T}_{\mathrm{m}}\right)$ were determined from the second heating cycle of the PLA fibers. The crystalline index $\left(\mathrm{X}_{\mathrm{c}}\right)$ was calculated according to Equation (5) (Dadbin and Kheirkhah, 2014):

$$
\mathrm{X}_{\mathrm{c}}(\%)=\frac{\Delta \mathrm{H}_{\mathrm{m}}-\Delta \mathrm{H}_{\mathrm{cc}}}{\mathrm{W} \cdot \Delta \mathrm{H}_{\mathrm{m} 0}} \cdot 100
$$

Where, $\Delta \mathrm{H}_{\mathrm{m}}$ is the melting enthalpy of the sample, $\Delta \mathrm{H}_{\mathrm{m} 0}$ is the melting enthalpy of $100 \%$ crystalline PLA, taken as $93 \mathrm{~J} / \mathrm{g}$ (Fortunati et al., 2012). $\Delta \mathrm{H}_{\mathrm{cc}}$ is the crystallization enthalpy and $\mathrm{W}$ is the weight fraction of PLA in the bionanocomposite fibers.

\section{Wide Angle X-Ray Scattering (WAXS)}

WAXS measurements were carried out on a Philips PW1050 diffractometer. The X-ray patterns were recorded in a range of 
$2-40^{\circ}$ with a step of $0.02^{\circ}$ and step time of $2 \mathrm{~s}$. The wavelength of the $\mathrm{Cu} / \mathrm{K} \alpha$ rod surface was $\lambda=0,154 \mathrm{~nm}$ and the spectra were obtained at $20 \mathrm{~mA}$ with an accelerating voltage of $40 \mathrm{eV}$.

\section{Thermogravimetric Analysis (TGA)}

Thermogravimetric analysis (TGA) was performed on a Perkin Elmer Pyris-1 TGA thermo-balance (PerkinElmer, Waltham, MA, USA) operating under $\mathrm{N}_{2}$ atmosphere in alumina crucibles containing around $10 \mathrm{mg}$ of material and ranging from 30 to $900^{\circ} \mathrm{C}$ at a heating rate of $10^{\circ} \mathrm{C} / \mathrm{min}$.

\section{Scanning Electron Microscopy (SEM)}

SEM images of the fibers were recorded using a QUANTA 200 FEG (FEI Company) environmental scanning electron microscope at an acceleration voltage of 7-10 keV. Prior to any observation in scanning mode (SEM), the transversal surfaces of the fibers were sputter coated with carbon using a Carbon Evaporator Device CED030 (Balzers), to ensure good surface conductivity and to avoid any degradation.

\section{Transmission Electron Microscopy (TEM)}

TEM observations were carried out on a JEOL 1200EX TEM scanning electron microscope operating at an accelerating voltage of $100 \mathrm{kV}$. The samples were embedded in a LR white resin and ultrathin-sectioned at $70 \mathrm{~nm}$ using a Leica EM UC7 ultra-microtome with a diamond knife Ultra 45 (Nissei Sangyo). The sections were transferred to carbon-coated $\mathrm{Cu}$ grids of 300 meshes.

\section{RESULTS AND DISCUSSION}

\section{Water Uptake (WU)}

Belonging to the family of aliphatic polyesters, PLA and its bionanocomposites absorb moisture when they are immersed in water or exposed to a humid atmosphere. Moisture uptake phenomenon leads to property changes and degrades also the materials through hydrolysis (Elsawy et al., 2017). In this regard, water uptake (WU) kinetics of PLA, PLA/PLA- $g$-MA/MCC1, and PLA/PLA- $g$-MA/CNW1 fibers were determined at 45 and $60^{\circ} \mathrm{C}$. The relative plots are shown in Figures 1A-D. Furthermore, the values of WU at saturation, diffusion coefficient, and activation energy are also provided in Table $\mathbf{1}$.

Figures 1A,B displays the curves of WU as a function of exposure time for PLA and PLA bionanocomposite fibers at 45 and $60^{\circ} \mathrm{C}$, respectively. As expected, WU capacity of PLA matrix is lower compared to that of its bionanocomposites. Nevertheless,
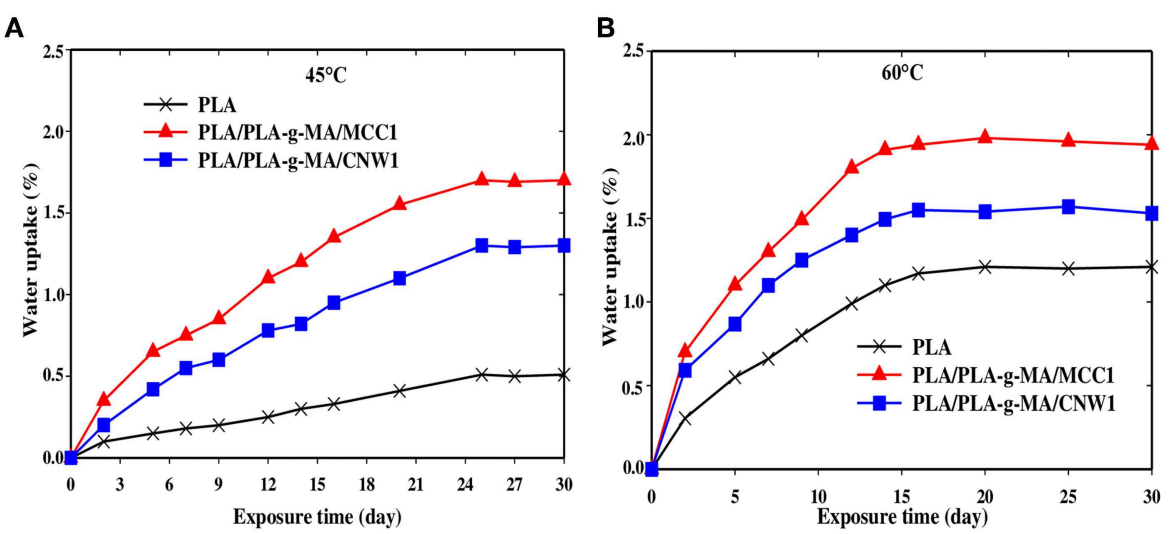

C

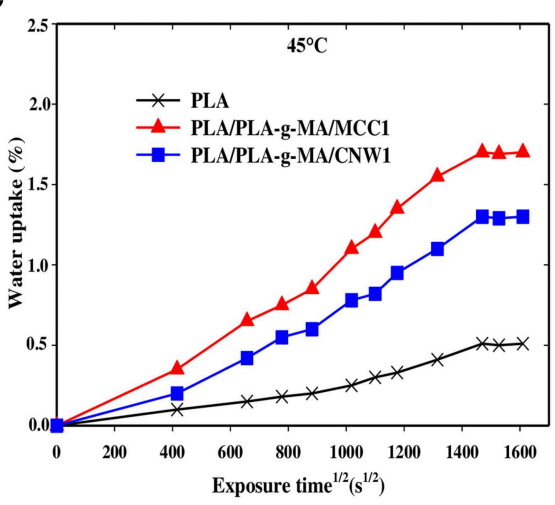

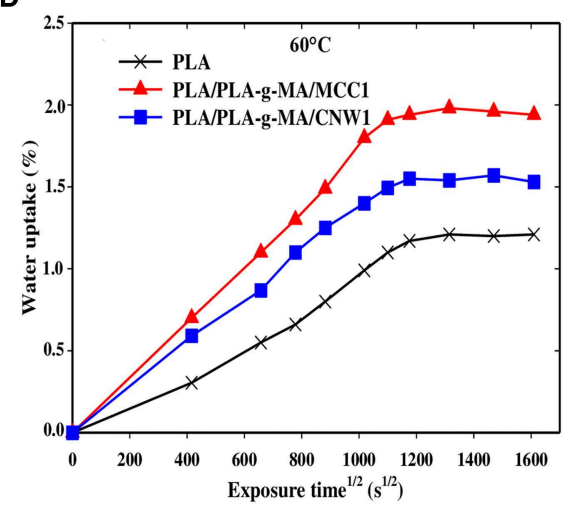

FIGURE 1 | Water uptake curves of PLA, PLA-g-MA/MCC1, and PLA-g-MA/CNW1 fibers vs. exposure time (A): $45^{\circ} \mathrm{C}$ and (B): $60^{\circ} \mathrm{C}$ and root of time (C) $45^{\circ} \mathrm{C}$ and (D): $60^{\circ} \mathrm{C}$, respectively in hygrothermal conditions. 
an increase in WU is observed for all fibers with increasing both exposure time and temperature, being less pronounced for PLA. It is also observed that for PLA bionanocomposite fibers filled with MCC1, WU \% is much higher than those filled with CNW1, whatever the temperature. This may be due to higher level of crystallinity in PLA/PLA- $g$-MA/CNW1. Indeed, the downward trend in WU of highly crystalline polymers has already been reported by many authors (Zhou and Xanthos, 2008; Balakrishnan et al., 2011; Hossain et al., 2014; Mitchell and Hirt, 2015), which is attributed on one hand, to the barrier effect of impermeable crystallites, and on the other hand, to the tortuosity of water diffusion into the polymeric matrix. In addition, the filler specific surface is another parameter, which has to be considered, since the larger the filler specific surface, the higher the amount of water trapped.

Figures 1C,D show that WU of all fibers increases almost linearly with the root of time at $60^{\circ} \mathrm{C}$ compared to $45^{\circ} \mathrm{C}$ before reaching saturation. This suggests that water diffusion in PLA fibers is governed by Fick's law, which is in agreement with the data reported in the literature (Yew et al., 2005; Balakrishnan et al., 2011; Ndazi and Karlsson, 2011; Chow et al., 2014; GilCastell et al., 2014; Hossain et al., 2014; Yu et al., 2018). The increase of WU of PLA and its bionanocomposites with time may also result from the formation of strong polar groups during hydrolysis process, mainly hydrophilic acid functions and also from the increase of the free volume in PLA matrix (Mortaigne, 2005; Zhou and Xanthos, 2008). Indeed, Gupta et al. (2012) reported a decrease in contact angle of PLA with time and subsequently, an increase of its polarity in the course of the hydrolysis process.

Table 1 shows that the activation energy value of PLA fiber is much higher than that of PLA bionanocomposites with 38 and $72 \%$ increases compared to that of PLA/PLA- $g$-MA/CNW1, and PLA/PLA- $g$-MA/MCC1, respectively. The lower WU value of PLA results from its higher relative hydrophobic character compared to that of the bionanocomposites. This is consistent with the literature data (Yew et al., 2005; Zhou and Xanthos, 2008; Balakrishnan et al., 2011; Yu et al., 2018) reporting WU values of PLA ranging from 0.5 to $1.0 \%$. In addition, the significant mass gain of PLA bionanocomposites over PLA mainly could be ascribed to the cellulosic fillers, which are highly hydrophilic materials. The presence of hydroxyl groups $(\mathrm{OH})$ in MCC and CNW is favorable for the occurrence of hydrogen bonding with moisture (Elsawy et al., 2017). This is in a good agreement with many authors who reported that the incorporation of natural hydrophilic fillers to PLA increases its WU capacity. These include cellulose nanowhiskers (Hossain et al., 2012), sisal fibers (Gil-Castell et al., 2014, 2016), ramie fibers (Yu et al., 2018), coconut fibers (Wu, 2009), and wood pulp (Azwar et al., 2012).

\section{Scission Index Evolution}

The hydrolytic degradation kinetics of PLA fibers and its bionanocomposite were investigated by determining the scission index (SI) with exposure time. The plots are shown in Figures 2A,B for PLA and the bionanocomposite fibers at 45

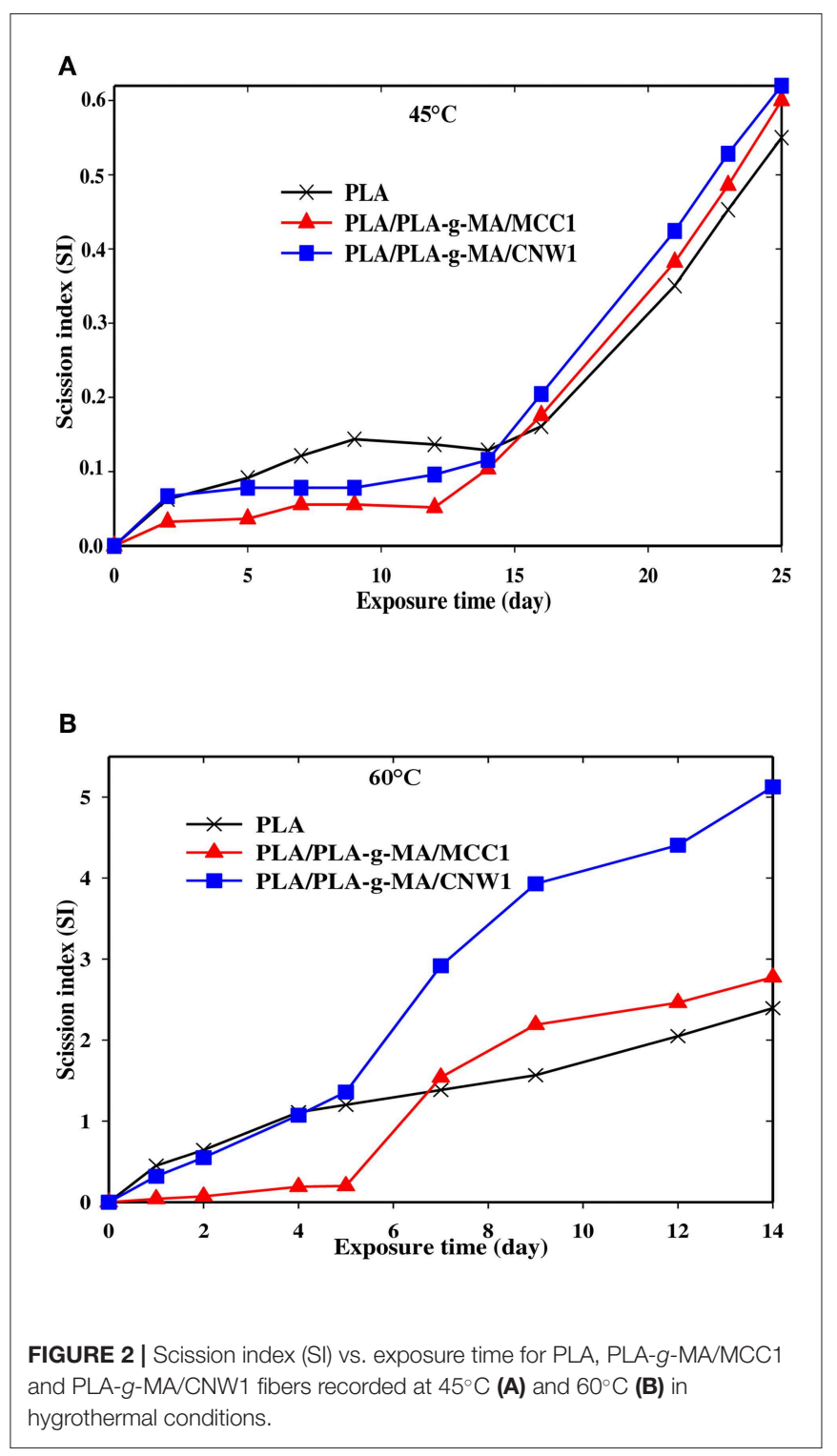

and $60^{\circ} \mathrm{C}$, respectively. Furthermore, Table 2 summarizes the $\mathrm{k}$ values, which give the hydrolysis rate of the exposed fibers.

In Figures 2A,B, there is an increasing evolution of SI curves with time for all PLA fibers whatever the temperature meaning that the degradation mechanism predominantly occurring in the matrix is chain scission (Gajjar and King, 2014; Gil-Castell et al., 2014). Indeed, the literature (Elsawy et al., 2017) reported that under humid conditions, hydrolysis reactions occur between PLA ester groups and water molecules resulting in chain scission forming chain segments with low molecular weight (Girdthep et al., 2016; Lins et al., 2016; Lorenzo et al., 2016; Mohammad et al., 2016; Pinese et al., 2016; Stloukal et al., 2016; Yang et al., 2016). Moreover, the hydrolysis of PLA bionanocomposites is strongly dependent on the intrinsic characteristics of PLA matrix, the nature of fillers, their dispersion in the polymer and the environment conditions (humidity and temperature) 
TABLE 2 | Hydrolysis parameters (hydrolysis rate constant k, coefficient of correlation $R^{2}$, timescale for diffusion and timescale of reaction) of PLA, PLA/PLA-g-MA/MCC1, and PLA/PLA-g-MA/CNW1 fibers at 45 and $60^{\circ} \mathrm{C}$ in hygrothermal conditions.

\begin{tabular}{|c|c|c|c|c|c|c|}
\hline \multirow[t]{2}{*}{ Fibers } & \multicolumn{2}{|c|}{$k\left(J^{-1}\right)$} & \multicolumn{2}{|c|}{$r^{2} / D_{e}(J)$} & \multicolumn{2}{|c|}{ 1/k (J) } \\
\hline & $45^{\circ} \mathrm{C}$ & $60^{\circ} \mathrm{C}\left(\mathrm{R}^{2}\right)$ & $45^{\circ} \mathrm{C}$ & $60^{\circ} \mathrm{C}$ & $45^{\circ} \mathrm{C}$ & $60^{\circ} \mathrm{C}$ \\
\hline PLA & $\begin{array}{c}0.0102 \\
R^{2}=0.85\end{array}$ & $\begin{array}{c}0.0568 \\
R^{2}=0.87\end{array}$ & $37 \times 10^{5}$ & $17 \times 10^{5}$ & 98 & 18 \\
\hline $\begin{array}{l}\text { PLA/PLA-g- } \\
\text { MA/MCC1 }\end{array}$ & $\begin{array}{c}0.0122 \\
R^{2}=0.82\end{array}$ & $\begin{array}{c}0.087 \\
R^{2}=0.95\end{array}$ & $25 \times 10^{5}$ & $15 \times 10^{5}$ & 81 & 11 \\
\hline $\begin{array}{l}\text { PLA/PLA-g- } \\
\text { MA/CNW1 }\end{array}$ & $\begin{array}{c}0.0125 \\
R^{2}=0.83\end{array}$ & $\begin{array}{c}0.1025 \\
R^{2}=0.90\end{array}$ & $26 \times 10^{5}$ & $16 \times 10^{5}$ & 80 & 10 \\
\hline
\end{tabular}

(Zhou and Xanthos, 2008; Maharana et al., 2009). In this regard, an increase in temperature from 45 to $60^{\circ} \mathrm{C}$, results in a fast hydrolysis process of PLA. Thus, the $\mathrm{k}$ values given in Table 3, indicate that all PLA fibers are more sensitive to hydrolysis at $60^{\circ} \mathrm{C}$ than $45^{\circ} \mathrm{C}$. Indeed, the $\mathrm{k}$ values of PLA, PLA/PLA$g$-MA/MCC1 and PLA/PLA- $g$-MA/CNW1 fibers recorded after 14 days at $60^{\circ} \mathrm{C}$ are 5,7 , and 8 times higher than after 25 days at $45^{\circ} \mathrm{C}$, respectively. At $60^{\circ} \mathrm{C}$, which is the $\mathrm{T}_{\mathrm{g}}$ of PLA, the chain mobility increases significantly, thus promoting water diffusion in the amorphous phase of PLA and subsequently a faster hydrolysis (Zhou and Xanthos, 2008; Balakrishnan et al., 2011; Castro-Aguirre et al., 2016). This is consistent with the data published by Copinet et al. (2004) and Zhou and Xanthos (2008) who reported a faster degradation of PLA at $60^{\circ} \mathrm{C}$ than at 45 and $50^{\circ} \mathrm{C}$. From Table 3, the catalytic role of cellulosic fillers on PLA hydrolysis is highlighted, especially at $60^{\circ} \mathrm{C}$. An increase in the $\mathrm{k}$ value by almost 53 and $80 \%$ is recorded for PLA/PLA- $g$-MA/MCC1 and PLA/PLA- $g$-MA/CNW1, respectively compared to that of neat PLA. This result is attributed to filler hydration, which is one of the key parameters responsible for accelerating the polymer hydrolytic degradation (Loo et al., 2005; Zhou and Xanthos, 2008). Accordingly, hydration phenomenon is explained by the easier accessibility to water of PLA in the presence of cellulosic fillers, which is in line with the water diffusion coefficient values shown in Table 1. Furthermore, the data provided in Table 2 show clearly the effect of the specific surface of the cellulosic filler on the hydrolysis of PLA. Although, the accessibility to water of PLA/PLA- $g$-MA/MCC1 is easier than that filled with CNW1 as shown in Table 1, it is however observed that the latter is more vulnerable to hygrothermal degradation. Indeed, Figure 2B shows the presence of a short induction period of about 5 days for PLA/PLA- $g$-MA/MCC1 fibers at $60^{\circ} \mathrm{C}$ up to 14 days, whereas the chain scission mechanism starts up on exposure for both PLA and PLA/PLA-g-MA/CNW1 fibers. This behavior is explained as a result of the high capacity of MCC to store the absorbed water, therefore reducing the wettability of PLA matrix. Unlike, CNW leads to better and homogeneous hydration of PLA matrix, thus promoting hydrolysis. Similarly, Kummerer et al. (2011) reported that cellulose nanocrystals are more sensitive to degradation than MCC in an aqueous environment. Table 2

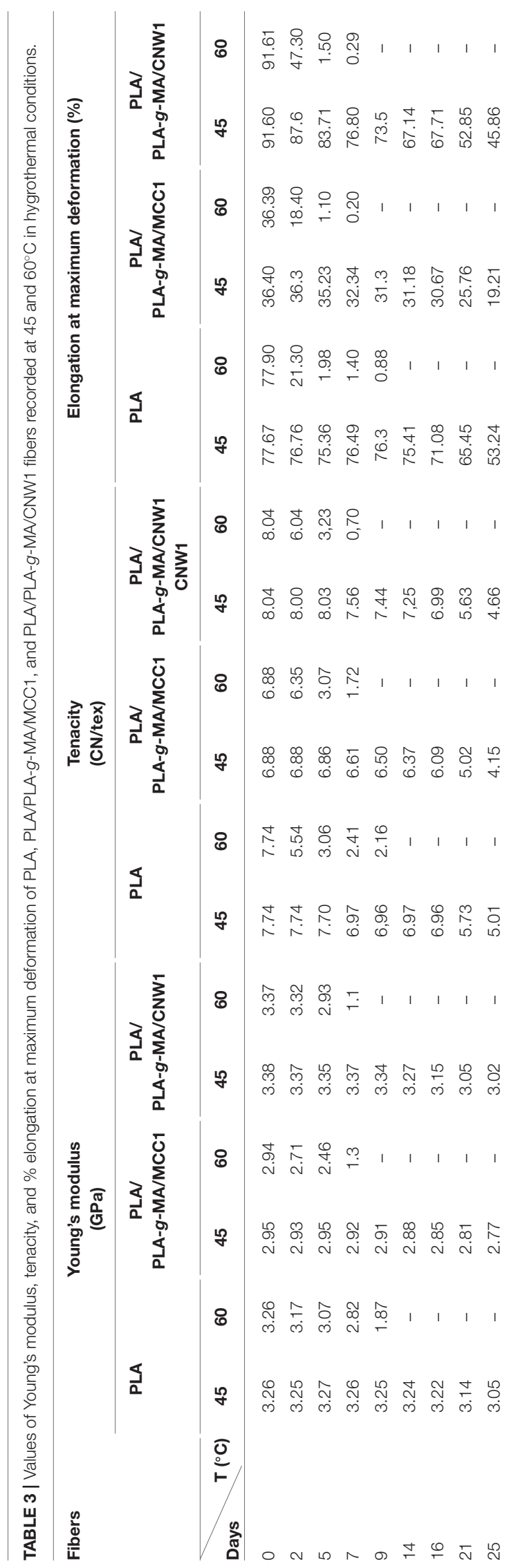


reports also the values of timescale for diffusion $\left(\mathrm{r}^{2} / \mathrm{De}\right)$ for all fibers, which are much higher than those of timescale of reaction $(1 / \mathrm{k})$ at both 45 and $60^{\circ} \mathrm{C}$. This indicates that the process of hydrolysis occurs mainly through a series of reactions rather than by a water diffusion process (Mitchell and Hirt, 2015).

\section{Morphological Characterization}

Figures 3-5 shows SEM images of both external and crosssectional surfaces of PLA and PLA bionanocomposite fibers before exposure and after 25 days at $45^{\circ} \mathrm{C}$ and 14 days at $60^{\circ} \mathrm{C}$. Figure 3a displays the external surface fiber of neat PLA before exposure. The surface is smooth and regular. After 25 days at $45^{\circ} \mathrm{C}$, no noticeable change was observed on the surface of neat PLA as shown in Figure 3b. However, after 14 days at $60^{\circ} \mathrm{C}$, some cracks were formed which were preferentially localized on the fiber sides (Figure 3c). Similar morphology has been observed by Yuan et al. (2002) on hygrothermal degradation of PLA fibers. In Figure 3d, the cross sectional surface fiber exhibits a homogeneous morphology, which seems intact without any damage. This result indicates that the hygrothermal aging of PLA occurs on the fiber surface rather than in the bulk. This is explained by the weak polarity of PLA which prevents the water diffusion from the surface to the bulk of material (Gupta et al.,
2012) in concordance with the WU data reported in Table 1. Figure 4a shows the SEM micrograph of the external surface of PLA/PLA-g-MA/MCC1 fiber before exposure. Although the surface appears smooth, its diameter is variable. Indeed, the diameter varies along the fiber passing from 65 to $100 \mu \mathrm{m}$, which is probably due to the presence of MCC aggregates of various sizes in PLA matrix. Figure $\mathbf{4 b}$ displays the external surface of PLA fiber filled with MCC1 after 25 days of exposure at $45^{\circ} \mathrm{C}$. The surface seems also smooth, however a decohesion between MCC and PLA matrix was observed. This phenomenon became more pronounced after 14 days at $60^{\circ} \mathrm{C}$ as shown in Figure $4 \mathrm{c}$ since many cracks were formed randomly at the fiber surface, playing a role of degradation precursors. Conversely to PLA fiber, it can be seen in Figure 4d that the hydrolytic degradation of PLA/PLA-g-MA/MCC1 occurs not only on the fiber surface, but also in the bulk as clearly demonstrated by the formation of internal crack starting from the surface to the filler aggregate. Figure 5a shows regular PLA/PLA- $g$-MA/CNW1 fibers with a diameter very close to that of neat PLA. The surface morphology of the fibers remained almost unchanged after 25 days of exposure at $45^{\circ} \mathrm{C}$ (Figure 5b). However, after 14 days at $60^{\circ} \mathrm{C}$, the bionanocomposite fiber was severely damaged with the appearance of a surface erosion phenomenon as shown
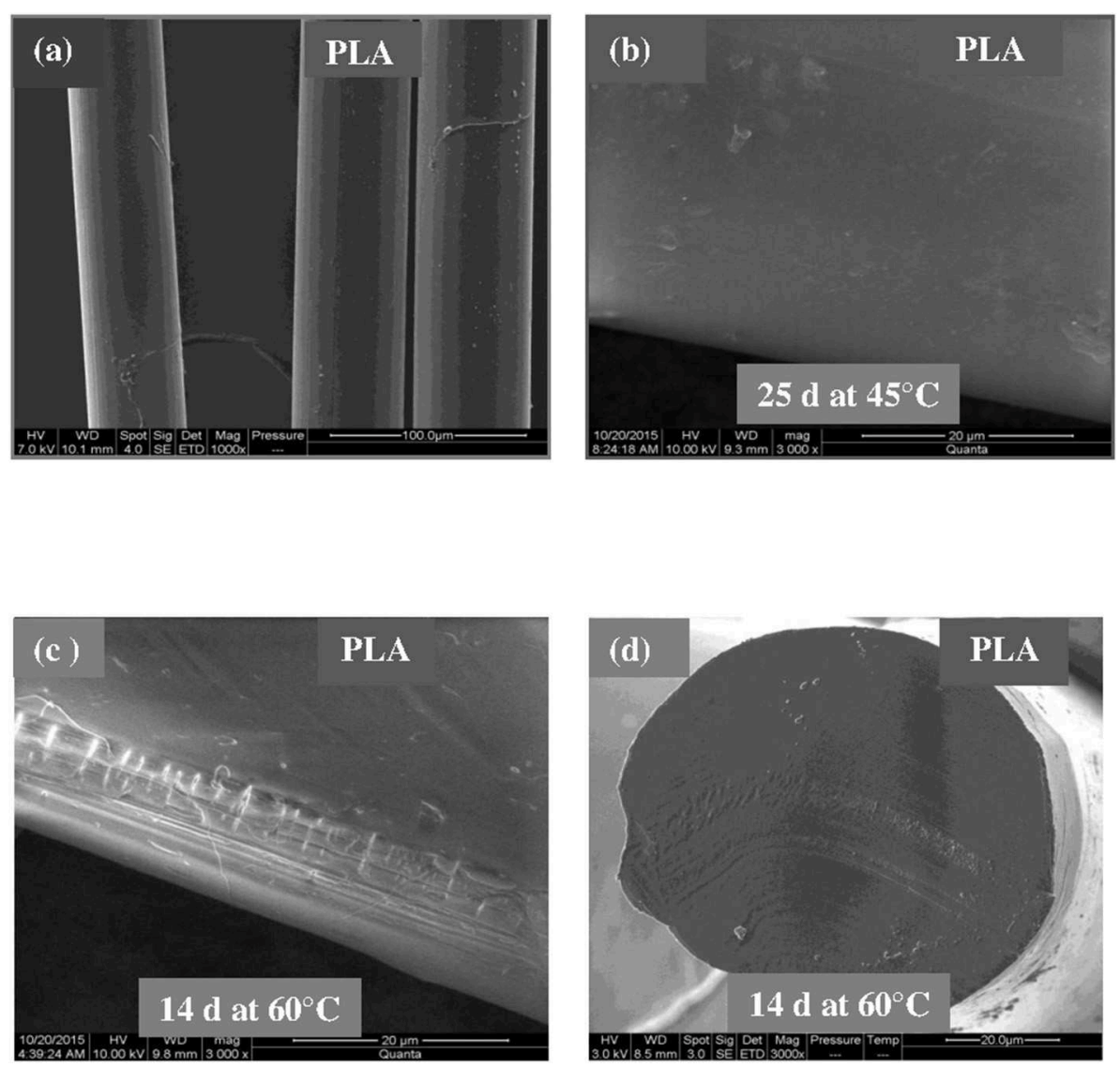

FIGURE 3 | SEM micrographs of external surface of a PLA fiber. (a) Before exposure, (b) after 25 days at $45^{\circ} \mathrm{C}$, (c) after 14 days at $60^{\circ} \mathrm{C}$, and (d) SEM micrograph of cross-sectional surface of a PLA fiber after 14 days at $60^{\circ} \mathrm{C}$. 

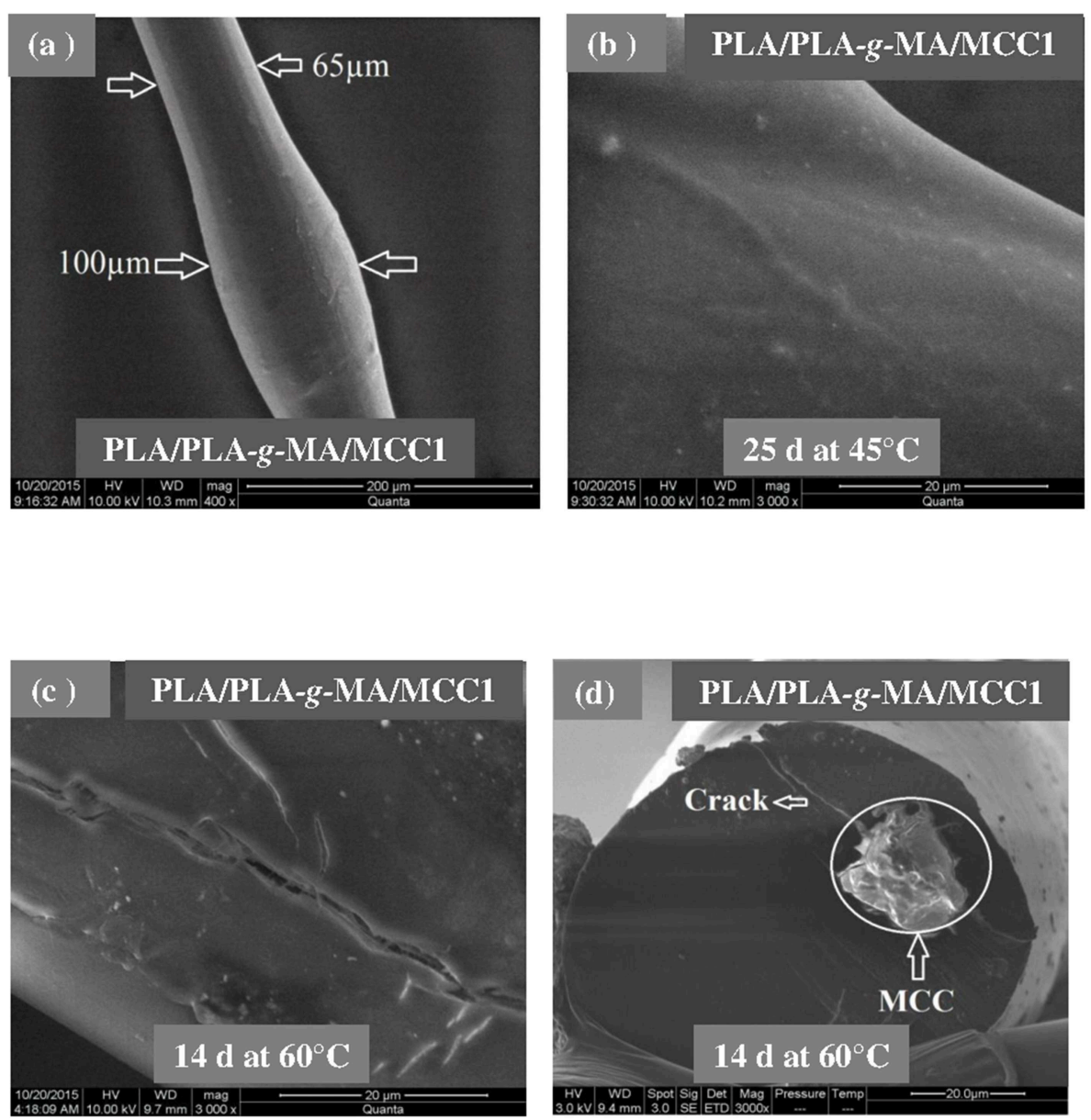

FIGURE 4 | SEM micrographs of external surface of a PLA/PLA-g-MA/MCC1 fiber. (a) Before exposure, (b) after 25 days at $45^{\circ} \mathrm{C}$, (c) after 14 days at $60^{\circ} \mathrm{C}$, and (d) SEM micrograph of cross-sectional surface of a PLA fiber after 14 days at $60^{\circ} \mathrm{C}$.

in Figure 5c. Further, cracks of almost $10 \mu \mathrm{m}$ long, regularly distributed on the surface and perpendicularly oriented to the fiber direction were observed. The cracks are probably formed due to the migration of various species including monomers and oligomers resulting from hydrolysis. In addition, the effect of hygrothermal aging on the morphological structure of neat PLA and PLA bionanocomposite fibers was also investigated by TEM. The corresponding TEM images are shown in Figures 6 and 7. Figure 6a shows the surface morphology of neat PLA before exposure. The sample exhibits a regular and homogenous morphology with no surface defects. After 25 days of exposure at $45^{\circ} \mathrm{C}$, some microvoids were observed on the fiber surface (Figure 6b), whose number and size seemed to increase with increasing the temperature to $60^{\circ} \mathrm{C}$ as illustrated in Figure 6c. In Figure 7a, which corresponds to PLA/PLA$g$-MA/CNW1 recorded before exposure, CNW particles are clearly distinguished from the PLA matrix by their whiteness and also by their typical rod shape. Figure $7 \mathbf{b}$ shows the presence of defects on the surface observed after 25 days at $45^{\circ} \mathrm{C}$. The morphology of the bionanocomposite fiber exhibits essentially microvoids similarly to neat PLA. However, after 14 days at $60^{\circ} \mathrm{C}$, the $\mathrm{CNW}$ particles appeared as black spots of higher density as clearly shown in Figure 7c. This means that $\mathrm{CNW}$ were completely disintegrated during hydrolysis at $60^{\circ} \mathrm{C}$. According to the literature (Pan et al., 2010; Ruiz et al., 2013), the aging of cellulosic fillers due to moisture uptake may lead to several structural and properties changes involving their depolymerization. At this stage, CNW showed a remarkable change in color from white to black (Dong et al., 1998; Jewena et al., 2016).

\section{Tensile Measurements}

Tensile properties, which are one of the main functional properties of polymers, are generally used as aging criteria to evaluate the durability of polymers in hygrothermal conditions (Chow et al., 2014). In this regard, tensile properties of PLA and PLA bionanocomposite fibers were investigated at 45 and $60^{\circ} \mathrm{C}$ and the data are summarized in Table 3 . In addition, the kinetics curves of tenacity of PLA fibers plotted at 45 and $60^{\circ} \mathrm{C}$ are shown in Figure 8. According to Table 3, elongation 

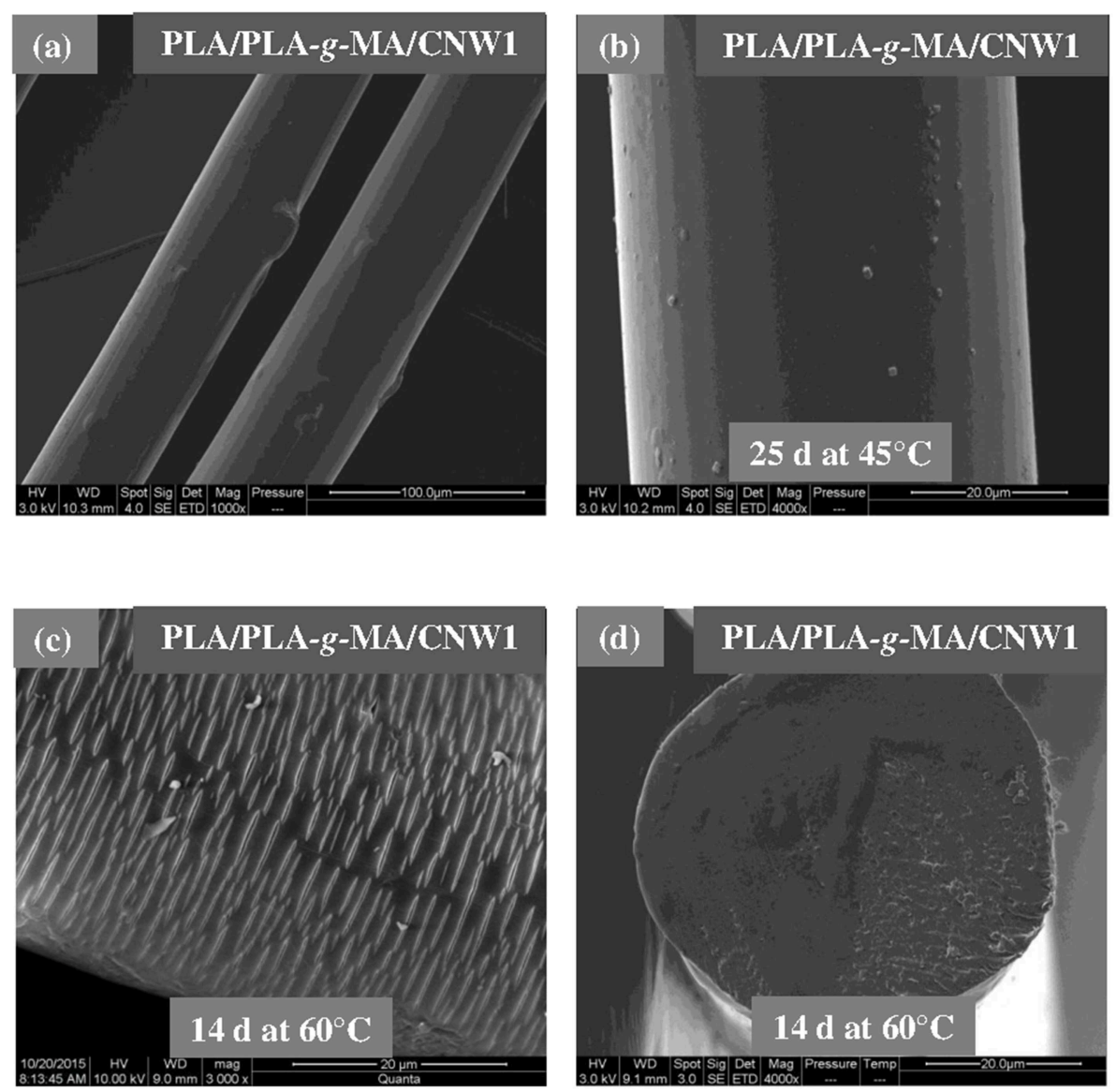

FIGURE 5 | SEM micrographs of external surface of a PLA/PLA-g-MA/CNW1 fiber. (a) Before exposure, (b) after 25 days at $45^{\circ} \mathrm{C}$, (c) after 14 days at $60^{\circ} \mathrm{C}$, and (d) SEM micrograph of cross-sectional surface of a PLA fiber after 14 days at $60^{\circ} \mathrm{C}$

at maximum deformation, Young's modulus and tenacity of the whole PLA fibers were reduced from hygrothermal exposure. Thus, at $45^{\circ} \mathrm{C}$ and after 25 days, the value of Young's modulus decreased by $\sim 8,10$, and $15 \%$ from the initial one for the neat PLA, PLA/PLA- $g$-MA/MCC1, and PLA/PLA- $g$-MA/CNW1, respectively. The decrease in Young's modulus may be attributed to the molecular weight decrease of PLA due to chain scission (Yu et al., 2018). Moreover, Table 3 shows also that the loss in tensile properties of the exposed PLA fibers is logically more pronounced at $60^{\circ} \mathrm{C}$ than $45^{\circ} \mathrm{C}$. Hence, after 7 days at $60^{\circ} \mathrm{C}$, the PLA fibers were no longer stretchable, while at $45^{\circ} \mathrm{C}$, the relative tenacity was almost stable up to 14 days. After this, a slight decrease in Young's modulus and elongation at maximum deformation was noted up to 25 days. It can be seen that the kinetics curves of relative tenacity and SI show similar trend. Whatever the filler specific surface, its incorporation in PLA matrix even at a very low content ratio, resulted in a decrease in the mechanical properties of the bionanocomposite fibers, especially at $60^{\circ} \mathrm{C}$. As a matter of fact, more than $92 \%$ decrease in the initial relative toughness of PLA/PLA- $g$-MA/CNW1 fibers were observed after 7 days at $60^{\circ} \mathrm{C}$, compared to $69 \%$ loss for the neat PLA. Water diffusion at filler-matrix interface, could cause a differential swelling due to the difference in absorption capacity between the cellulosic filler and PLA resulting in the bionanocomposite degradation (Le Duigou et al., 2009; Yu et al., 2018). This corroborates the TEM analysis on the morphology of PLA/PLA-g-MA/CNW1 fibers, which clearly shows the complete disintegration of $\mathrm{CNW}$ particles causing structural defects, which are responsible for the deterioration of the tensile properties.

\section{Thermal Properties}

The effect of hygrothermal aging on thermal properties of neat PLA and PLA bionanocomposite fibers was investigated by DSC at 45 and $60^{\circ} \mathrm{C}$. The detailed data recorded at the second heating cycle, are presented in Table 4. From the data in Table 4, $\mathrm{T}_{\mathrm{g}}$, $\mathrm{T}_{\mathrm{cc}}, \mathrm{T}_{\mathrm{m}}$, and $\mathrm{X}_{\mathrm{c}}$ remained almost unchanged for all fibers at $45^{\circ} \mathrm{C}$ until 14 days of exposure. After this, $\mathrm{T}_{\mathrm{g}}$ and $\mathrm{T}_{\mathrm{cc}}$ slightly decreased by 1 and $2{ }^{\circ} \mathrm{C}$, respectively, while $\mathrm{X}_{\mathrm{c}}$ of neat PLA, PLA/PLA- $g$-MA/MCC1, and PLA/PLA- $g$-MA/CNW1 increased by $2.2,1.2$, and 1.5 times, respectively compared to their initial values. However, at $60^{\circ} \mathrm{C}$, the thermal characteristics of PLA 

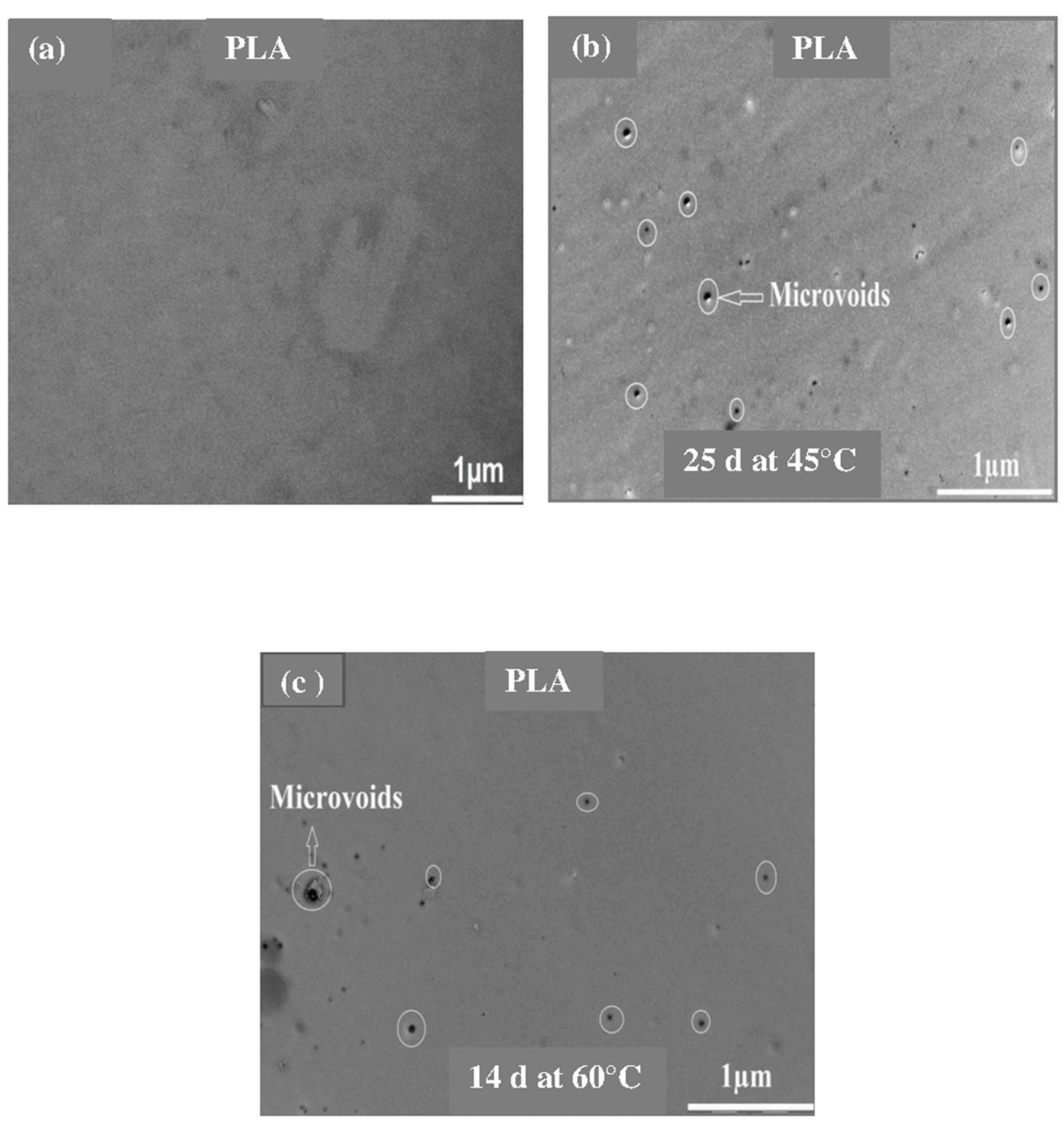

FIGURE 6 | TEM images of a PLA fiber. (a) Before exposure, (b) after 25 days at $45^{\circ} \mathrm{C}$, and (c) 14 days at $60^{\circ} \mathrm{C}$.

fibers, especially $\mathrm{X}_{\mathrm{c}}$, were significantly affected after 14 days of exposure. The hydrolytic splitting-chains of PLA, which proceeds preferentially in the amorphous regions, led to the formation of short chain segments (Yuan et al., 2002; Zhou and Xanthos, 2008) having enough energy to rearrange themselves and subsequently to crystallize (Loo et al., 2005; Zhang et al., 2008). This is in a good agreement with the data reported by Mitchell and Hirt (2015) who indicated an increase in $\mathrm{X}_{c}$ of PLA fibers from 11 to $41 \%$ after only $24 \mathrm{~h}$ at $60^{\circ} \mathrm{C}$ and $100 \% \mathrm{RH}$. Moreover, the cold crystallization temperature $\left(\mathrm{T}_{\mathrm{cc}}\right)$ decreased considerably with exposure time at $60^{\circ} \mathrm{C}$. This is consistent with the decrease in the activation energy, which promotes the chain mobility and subsequently, the crystallization process of PLA (Zhou and Xanthos, 2008; Chen et al., 2012; Santonja-Blasco et al., 2013). Furthermore, the incorporation of MCC and CNW into PLA matrix, even at a very low content, significantly reduced the thermal properties of the biocomposite material. Table 4 indicates also a slight decrease in melting temperature $\left(\mathrm{T}_{\mathrm{m}}\right)$ for the bionanocomposite fibers with exposure time. This is often attributed to the formation of less perfect crystallites or less thermally stable ones which melt at low temperature (Zhang et al., 2008; Chen et al., 2012; Mitchell and Hirt, 2015). The presence of a double melting point in the DSC thermograms (not shown) for both PLA and PLA/PLA-g-MA/MCC1 fibers may result from complex phenomena involving polymorphism, melting-recrystallization-melting or short chains reorganization phenomena during heating (Ling and Spruiell, 2006; Shieh and Liu, 2007; Murariu et al., 2012; Santonja-Blasco et al., 2013). The lower melting peaks correspond to the imperfect crystallites, while the higher ones correspond to the perfect ones ( $\mathrm{Ma}$ and Zhou, 2015).

\section{Crystallinity Measurement by WAXS}

The crystallinity structure of PLA and PLA bionanocomposite fibers was also investigated by WAXS at 45 and $60^{\circ} \mathrm{C}$. The relative patterns are shown in Figure 9. It can be seen that all PLA fibers display a typical amorphous pattern before exposure. However, the semicristalline structure of PLA clearly appears on the WAXS spectra at $45^{\circ} \mathrm{C}$, even more at $60^{\circ} \mathrm{C}$. Thus, two peaks are observed; the most intense one is localized at $2 \theta=$ 

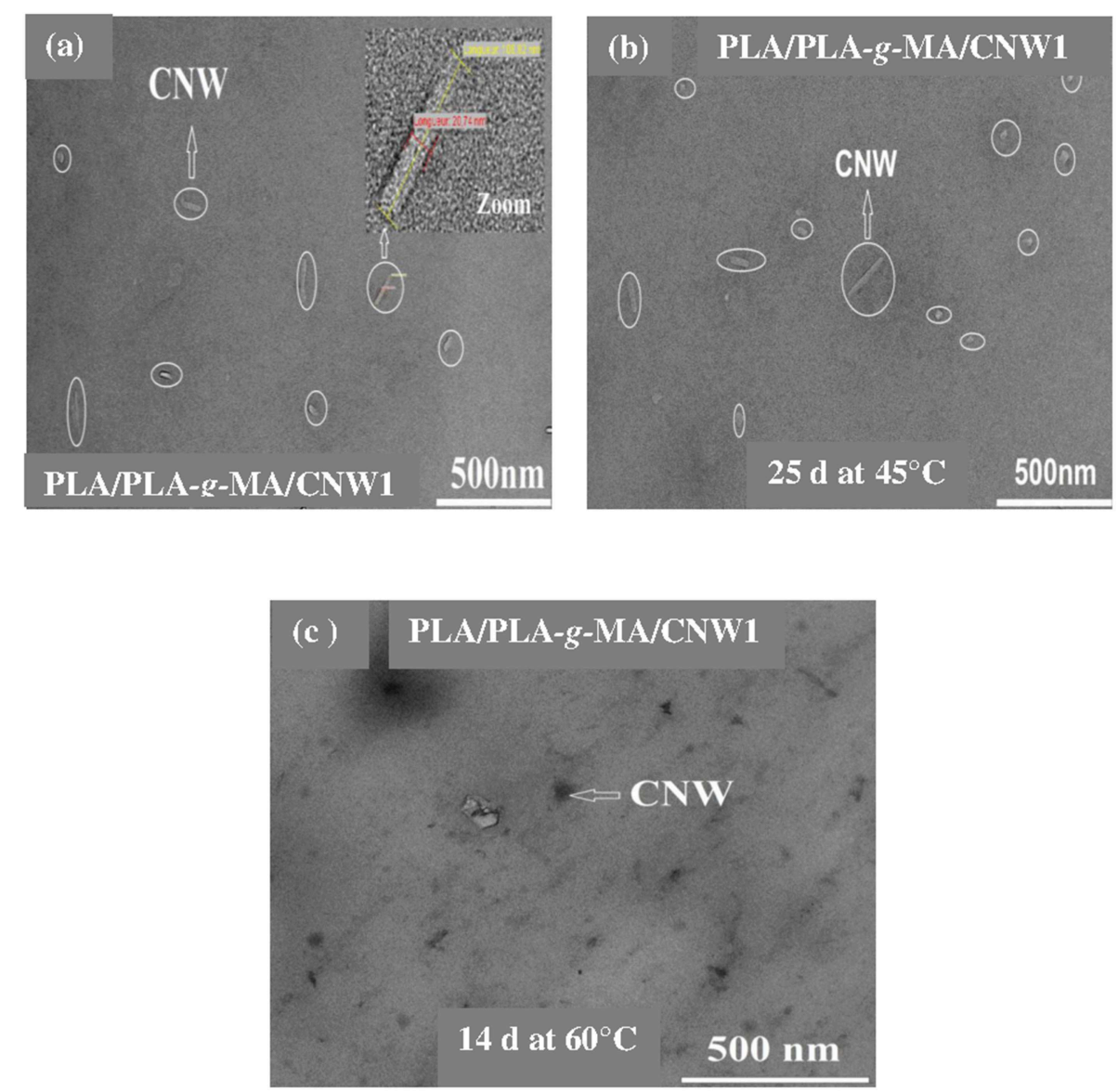

FIGURE 7 | TEM images of a PLA/PLA-g-MA/CNW1 fiber. (a) Before exposure, (b) after 25 days at $45^{\circ} \mathrm{C}$, and (c) 14 days at $60^{\circ} \mathrm{C}$.

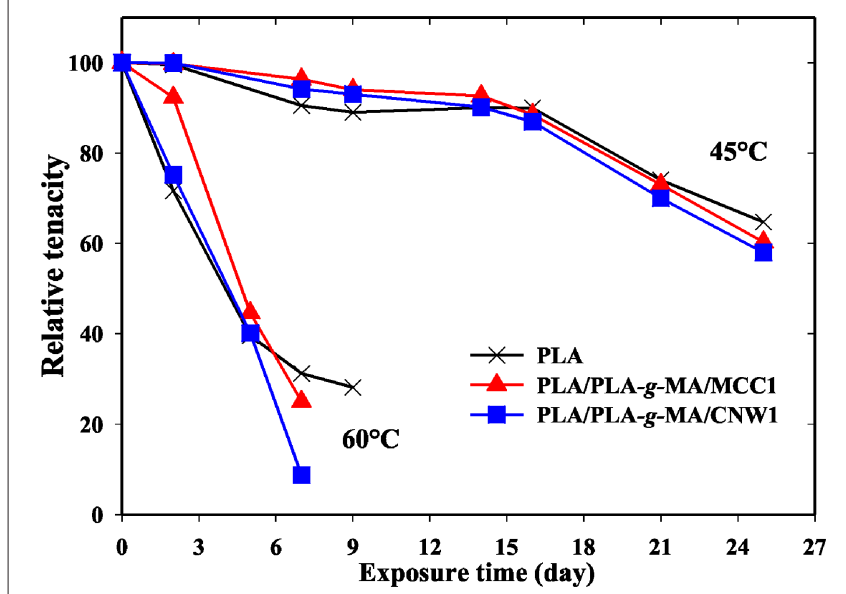

FIGURE 8 | Relative tenacity as a function of exposure time for PLA,

PLA/PLA-g-MA/MCC1, and PLA/PLA-g-MA/CNW1 fibers recorded at 45 and $60^{\circ} \mathrm{C}$ in hygrothermal conditions.

$16.7^{\circ}$ corresponding to the crystallographic planes $(110,200)$ of PLA crystallites (Sullivan et al., 2015), while a second peak of less intensity is centered at $2 \theta=18.9^{\circ}$, which is relative to the
(203) plane (Chen et al., 2012). The remarkable increase in peak intensity at $2 \theta=16.7$ and $18.9^{\circ}$ in PLA fibers at $60^{\circ} \mathrm{C}$ up to 14 days is attributed to the increase in crystallinity of PLA and its bionanocomposites, however much higher for PLA/PLA-gMA/CNW1. This result is consistent with the scission index (SI) and DSC data.

\section{Thermal Stability}

The effect of hygrothermal exposure on the thermal stability of PLA and its bionanocomposite fibers was investigated by TGA. Table 5 summarizes the values of degradation temperature at 5 wt $\%$ loss $\left(\mathrm{T}_{5 \%}\right)$ and $50 \mathrm{wt} \%$ loss $\left(\mathrm{T}_{50 \%}\right)$ with exposure time. It is observed that $\mathrm{T}_{5 \%}$ of PLA fibers decreased significantly at $60^{\circ} \mathrm{C}$, while $\mathrm{T}_{50 \%}$ was almost unchanged, particularly at $45^{\circ} \mathrm{C}$. This is in a good agreement with the data published by Gil-Castell et al. (2016) who reported that the temperature at maximum degradation rate of PLA and PLA/sisal biocomposites remains constant after hydrolysis in water at $85^{\circ} \mathrm{C}$, while the onset degradation temperature decreases significantly. Table 5 shows also that after 14 days at $60^{\circ} \mathrm{C}, \mathrm{T}_{5 \%}$ decreased considerably by 22,52 , and $56^{\circ} \mathrm{C}$ for neat PLA, PLA/PLA-g-MA/MCC1, and PLA/PLA- $g$-MA/CNW1, respectively. This is attributed to the catalytic role of cellulosic fillers in PLA, which accelerates 
TABLE 4 | Thermal characteristics $\left(T_{g}, T_{c c}, T_{m}\right.$, and $X_{c}$ ) of PLA, PLA/PLA-g-MA/MCC1, and PLA/PLA-g-MA/CNW1 fibers recorded at 45 and $60^{\circ} \mathrm{C}$ in hygrothermal conditions.

\begin{tabular}{|c|c|c|c|c|c|c|c|c|c|c|c|}
\hline \multirow[t]{3}{*}{ Fibers } & \multirow{3}{*}{$\begin{array}{c}\text { Exposure time } \\
\text { (days) }\end{array}$} & \multicolumn{2}{|c|}{$\mathrm{T}_{\mathrm{g}}\left({ }^{\circ} \mathrm{C}\right)$} & \multicolumn{2}{|c|}{$\mathrm{T}_{\mathrm{cc}}\left({ }^{\circ} \mathbf{C}\right)$} & \multicolumn{4}{|c|}{$\mathrm{T}_{\mathrm{m}}\left({ }^{\circ} \mathrm{C}\right)$} & \multicolumn{2}{|c|}{$X_{c}(\%)$} \\
\hline & & $45^{\circ} \mathrm{C}$ & $60^{\circ} \mathrm{C}$ & $45^{\circ} \mathrm{C}$ & $60^{\circ} \mathrm{C}$ & $45^{\circ} \mathrm{C}$ & $60^{\circ} \mathrm{C}$ & $45^{\circ} \mathrm{C}$ & $60^{\circ} \mathrm{C}$ & & \\
\hline & & & & & & $T_{m 1}$ & $\mathbf{T}_{\mathrm{m} 2}$ & $\mathbf{T}_{\mathrm{m} 1}$ & $\mathbf{T}_{\mathrm{m} 2}$ & & \\
\hline \multirow[t]{8}{*}{ PLA } & 0 & 59.6 & 59.6 & 117.9 & 117.9 & 151.3 & - & 151.3 & - & 0.5 & 0.5 \\
\hline & 2 & 59.2 & 59.6 & 117.2 & 116.6 & 151.1 & - & 151.3 & 156.2 & 0.6 & 0.7 \\
\hline & 7 & 59.2 & 58.6 & 117.4 & 113.8 & 151.4 & - & 151.5 & 157.6 & 0.7 & 1.6 \\
\hline & 9 & 59.4 & 57.9 & 117.1 & 108.7 & 151.1 & - & 151.5 & 158.4 & 0.7 & 3.2 \\
\hline & 14 & 59.8 & 56.3 & 117.2 & 106.6 & 151.3 & 155.0 & 152.1 & 159.7 & 0.8 & 5.3 \\
\hline & 16 & 58.9 & - & 116.9 & - & 151.3 & 155.3 & - & - & 0.8 & - \\
\hline & 21 & 58.6 & - & 116.5 & - & 151.3 & 156.2 & - & - & 1.0 & - \\
\hline & 25 & 58.1 & - & 115.2 & - & 151.4 & 156.3 & - & - & 1.1 & - \\
\hline \multirow[t]{8}{*}{ PLA/PLA-g-MA/MCC1 } & 0 & 58.8 & 58.8 & 128.2 & 128.2 & 154.8 & - & 154.8 & - & 1.8 & 1.8 \\
\hline & 2 & 58.3 & 58.8 & 127.5 & 125.5 & 154.7 & - & 154.7 & - & 1.8 & 1.8 \\
\hline & 7 & 58.9 & 58.0 & 127.9 & 123.3 & 155.8 & - & 154.0 & 158.9 & 1.8 & 2.2 \\
\hline & 9 & 58.4 & 56.9 & 129.0 & 121.3 & 154.6 & - & 152.4 & 158.6 & 1.7 & 3.5 \\
\hline & 14 & 58.6 & 54.1 & 128.5 & 111.3 & 155.6 & - & 151.4 & 158.1 & 1.8 & 7.5 \\
\hline & 16 & 57.7 & - & 127.7 & - & 154.1 & - & - & - & 1.9 & - \\
\hline & 21 & 57.653 & - & 127.0 & - & 154.0 & - & - & - & 2.1 & - \\
\hline & 25 & 57.2 & - & 126.6 & - & 153.7 & - & - & - & 2.2 & - \\
\hline \multirow[t]{8}{*}{ PLA/PLA-g-MA/CNW1 } & 0 & 61.5 & 61.5 & 111.8 & 111.8 & 158.4 & 165.8 & 158.4 & 165.8 & 5.3 & 5.3 \\
\hline & 2 & 61.3 & 60.4 & 111.3 & 109.0 & 158.8 & 165.8 & 158.3 & 165.6 & 5.4 & 7.5 \\
\hline & 7 & 61.6 & 58.6 & 111.7 & 104.5 & 158.7 & 165.6 & - & 166.0 & 5.3 & 15.9 \\
\hline & 9 & 61.0 & 58.5 & 111.0 & 101.7 & 158.2 & 165.8 & - & 164.5 & 5.8 & 17.3 \\
\hline & 14 & 61.5 & 54.3 & 111.3 & 95.1 & 158.3 & 165.8 & - & 161.9 & 5.8 & 22.2 \\
\hline & 16 & 60.7 & - & 110.9 & - & 157.8 & 165.0 & - & - & 6.1 & - \\
\hline & 21 & 59.9 & - & 110,0 & - & 157.2 & 164.6 & - & - & 7.8 & - \\
\hline & 25 & 59.7 & - & 108.9 & - & 157.1 & 164.1 & - & - & 8.1 & - \\
\hline
\end{tabular}

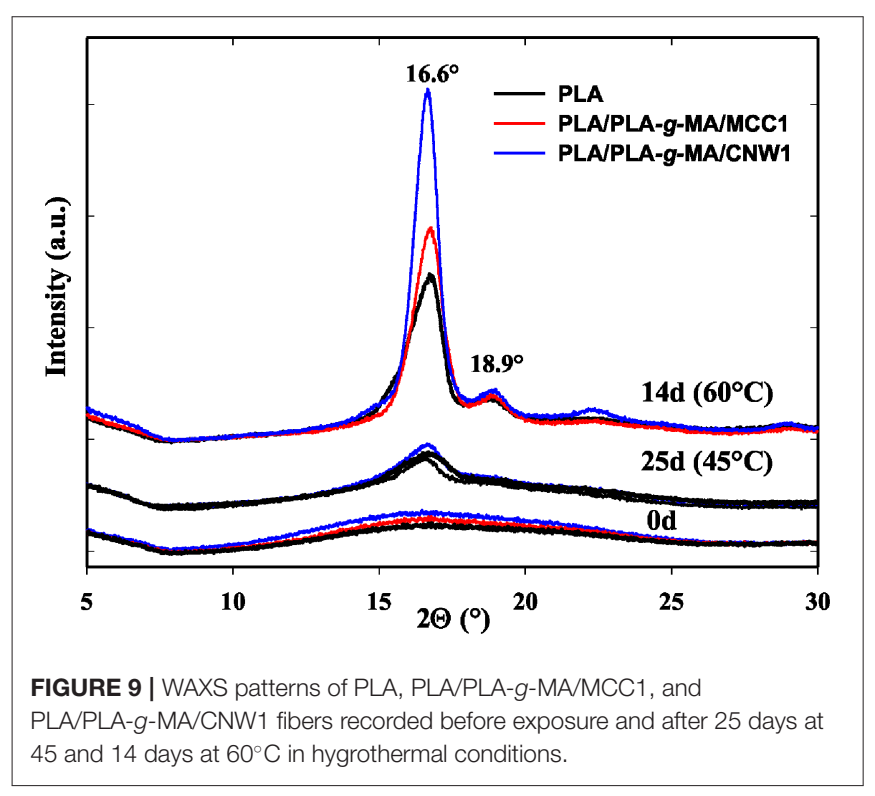

the hydrolysis process and consequently increases the fraction of short-length fragments, which can degrade at relatively low temperature (Gupta et al., 2012).

\section{CONCLUSION}

From this study, it can be concluded that under hygrothermal conditions $\left(45 / 60^{\circ} \mathrm{C}\right.$ and $\left.95 \% \mathrm{RH}\right)$, both PLA fibers and those based on PLA/PLA- $g$-MA/MCC1 and PLA/PLA- $g$-MA/CNW1 bionanocomposites undergo hydrolytic degradation, which proceeds mainly by chain scission mechanism. Consequently, an increase in SI and a decrease in $\mathrm{T}_{5 \%}$ and tensile properties (tenacity, modulus and elongation at maximum deformation) are observed for all samples, however more pronounced for the PLA bionanocomposite fibers. The decrease in properties depends on filler specific surface and temperature. After 14 days at $60^{\circ} \mathrm{C}$, the hydrolysis rate constant is estimated to 5, 7, and 8 times faster for PLA, PLA/PLA-g-MA/MCC1, and PLAPLA-g-MA/CNW1, respectively compared to that recorded after 25 days at $45^{\circ} \mathrm{C}$. 
TABLE 5 | TGA data ( $T_{5 \%}$ and $T_{50 \%}$ ) of PLA, PLA/PLA-g-MA/MCC1, and PLA/PLA-g-MA/CNW1 fibers recorded at 45 and $60^{\circ} \mathrm{C}$ in hygrothermal conditions.

\begin{tabular}{|c|c|c|c|c|c|c|c|c|c|c|c|c|}
\hline \multirow{3}{*}{$\begin{array}{l}\text { Fibers } \\
\text { Days } \mathrm{T}\left({ }^{\circ} \mathrm{C}\right)\end{array}$} & \multicolumn{6}{|c|}{$\mathbf{T}_{5 \%}\left({ }^{\circ} \mathbf{C}\right)$} & \multicolumn{6}{|c|}{$\mathbf{T}_{50 \%}\left({ }^{\circ} \mathbf{C}\right)$} \\
\hline & \multicolumn{2}{|c|}{ PLA } & \multicolumn{2}{|c|}{$\begin{array}{c}\text { PLA/ } \\
\text { PLA-g-MA/ } \\
\text { MCC1 }\end{array}$} & \multicolumn{2}{|c|}{$\begin{array}{c}\text { PLA/ } \\
\text { PLA-g-MA/ } \\
\text { CNW1 }\end{array}$} & \multicolumn{2}{|c|}{ PLA } & \multicolumn{2}{|c|}{$\begin{array}{c}\text { PLA/ } \\
\text { PLA-g-MA/ } \\
\text { MCC1 }\end{array}$} & \multicolumn{2}{|c|}{$\begin{array}{c}\text { PLA/ } \\
\text { PLA-g-MA/ } \\
\text { CNW1 }\end{array}$} \\
\hline & 45 & 60 & 45 & 60 & 45 & 60 & 45 & 60 & 45 & 60 & 45 & 60 \\
\hline 0 & 316 & 316 & 327 & 327 & 332 & 332 & 360 & 360 & 362 & 362 & 363 & 363 \\
\hline 2 & 317 & 308 & 328 & 322 & 329 & 325 & 361 & 360 & 360 & 362 & 362 & 362 \\
\hline 7 & 317 & 304 & 325 & 314 & 328 & 311 & 360 & 360 & 361 & 361 & 360 & 360 \\
\hline 9 & 316 & 298 & 326 & 299 & 328 & 297 & 360 & 359 & 360 & 360 & 360 & 359 \\
\hline 14 & 315 & 294 & 324 & 275 & 324 & 276 & 361 & 360 & 360 & 357 & 360 & 356 \\
\hline 16 & 310 & - & 323 & - & 322 & - & 359 & - & 362 & - & 361 & - \\
\hline 21 & 302 & - & 318 & - & 316 & - & 361 & - & 359 & - & 363 & - \\
\hline 25 & 309 & - & 314 & - & 309 & - & 359 & - & 360 & - & 361 & - \\
\hline
\end{tabular}

Moreover, crystallinity and crystallization rate of PLA fibers show a substantial increase during their exposure to hygrothermal aging. SEM observations show damaged topographies for all exposed fibers after 14 days at $60^{\circ} \mathrm{C}$ compared to those recorded after 25 days at $45^{\circ} \mathrm{C}$ due probably to the molecular mobility in the vicinity of the glass transition temperature of PLA $\left(60^{\circ} \mathrm{C}\right)$. On the basis of all the results obtained, the durability of PLA fibers to hygrothermal degradation is established in the following order: PLA > PLA/PLA- $g$-MA/MCC1 > PLA/PLA- $g$ MA/CNW1.

\section{DATA AVAILABILITY STATEMENT}

The raw data supporting the conclusions of this article will be made available by the authors, without undue reservation, to any qualified researcher.

\section{REFERENCES}

Aouat, T., Kaci, M., Devaux, E., Campagne, C., Cayla, A., Dumazert, L., et al. (2018). Morphological, mechanical and thermal characterization of poly(lactic acid)/cellulose multifilament fibers prepared by melt spinning. Adv. Polym Technol. 37:21779. doi: 10.1002/adv.21779

Azwar, E., Vuorinen, E., and Hakkarainen, M. (2012). Pyrolysis-GC-MS reveals important differences in hydrolytic degradation process of wood flour and rice bran filled polylactide composites. Polym. Degrad. Stab. 97, 281-287. doi: 10.1016/j.polymdegradstab.2011.12.017

Balakrishnan, H., Hassan, A., Imran, M., and Wahit, M. U. (2011). Aging of toughened poly(lactic acid) nanocomposites: water absorption, hygrothermal degradation and soil burial analysis. J. Polym. Env. 19, 863-875. doi: 10.1007/s10924-011-0338-9

Bayart, M., Gauvin, F., Foruzanmehr, R., Elkoun, S., and Robert, M. (2017). Mechanical and moisture absorption characterization of PLA composites reinforced with nano-coated flax fibers. Fibers Polym. 18, 1288-1295. doi: 10.1007/s12221-017-7123-x

Castro-Aguirre, E., Iniguez-Franco, F., Samsudin, H., Fang, X., and Auras, R. (2016). Poly(lactic acid)-mass production, processing, industrial applications, and end of life. Adv. Drug Deliv. Rev. 107, 333-336. doi: 10.1016/j.addr.2016.03.010

\section{AUTHOR CONTRIBUTIONS}

This manuscript has been written by MK. The manuscript is a part of the Ph.D. thesis of TA who has conducted the experimental work as well as the interpretation of the results. J-ML-C received TA in his laboratory for scientific internships several times, especially for the study of characterization of the morphology and properties of PLA fibers. ED received also TA in his laboratory for scientific internships several times for the preparation of the PLA, fibers by meltspinning process.

\section{ACKNOWLEDGMENTS}

TA would like to thank the technical staff of ENSAIT Roubaix (France) and IMT Mines Alès (France) for their help to realize the experimental work.

Chen, H., Chen, J., Chen, J., Yang, J., Huang, T., Zhang, N., et al. (2012). Effect of organic montmorillonite on cold crystallization and hydrolytic degradation of poly(L-lactide). Polym. Degrad. Stab. 97, 2273-2283. doi: 10.1016/j.polymdegradstab.2012.07.037

Chow, W. S., Leu, Y. Y., and Mohd Ishak, Z. A. (2014). Water absorption of poly(lactic acid) nanocomposites: effects of nanofillers and maleated rubbers. Polym.-Plast. Technol. Eng. 53, 858-863. doi: 10.1080/03602559.2014.886054

Copinet, A., Bertrand, C., Govindin, S., Coma, V., and Couturier, Y. (2004). Effects of ultraviolet light $(315 \mathrm{~nm})$, temperature and relative humidity on the degradation of polylactic acid plastic films. Chemosphere 55, 763-773. doi: 10.1016/j.chemosphere.2003.11.038

Dadbin, S., and Kheirkhah, Y. (2014). Gamma irradiation of melt processed biomedical PDLLA/HAP nanocomposites. Radiat. Phys. Chem. 97, 270-274. doi: 10.1016/j.radphyschem.2013.12.001

Dong, X.-M., Revol, J., and Gray, D. (1998). Effect of microcrystalline preparation conditions on the formation of colloid crystals of cellulose. Cellulose 5, 19-32. doi: 10.1023/A:1009260511939

Elsawy, M. A., Kim, K.-H., Park, J.-W., and Deep, A. (2017). Hydrolytic degradation of poly(lactic acid) (PLA) and its composites. Renew. Sustain. Energy Rev. 79, 1346-1352. doi: 10.1016/j.rser.2017.05.143

Fayolle, B., and Verdu, J. (2005). Vieillissement Physique des Matériaux Polymères. Techniques de l'Ingénieur. COR 108 V1. 
Fortunati, E., Armentano, I., Zhou, Q., Puglia, D., Terenzi, A., Berglund, L. A., et al. (2012). Microstructure and nonisothermal cold crystallization of PLA composites based on silver nanoparticles and nanocrystalline cellulose. Polym. Degrad. Stab. 97, 2027-2036. doi: 10.1016/j.polymdegradstab.2012.03.027

Gajjar, C. R., and King, M. W. (2014). Resorbable Fiber-Forming Polymers in Biotextile Applications. (Raleigh, NC: Springer), 7-11.

Gil-Castell, G., Badia, J., Kittikorn, T., Strömberg, E., Ek, M., Karlsson, S., et al, (2016). Impact of hydrothermal ageing on the thermal stability, morphology and viscoelastic performance of PLA/sisal biocomposites. Polym. Degrad. Stab. 132, 87-96. doi: 10.1016/j.polymdegradstab.2016.03.038

Gil-Castell, O., Badia, J. D., Kittikorn, T., Stromberg, E., and Martinez-Felipe, A. (2014). Hydrothermal ageing of polylactide/sisal biocomposites. studies of water absorption behaviour and physico-chemical performance. Polym. Degrad. Stab. 108, 212-222. doi: 10.1016/j.polymdegradstab.2014.06.010

Girdthep, S., Worajittiphon, P., Leejarkpai, T., and Molloy, R. (2016). Effect of silver-loaded kaolinite on real ageing, hydrolytic degradation, and biodegradation of composite blown films based on poly(lactic acid) and poly(butylene adipate-co-terephthalate). Eur. Polym. J. 82, 244-259. doi: 10.1016/j.eurpolymj.2016.07.020

Gupta, B., Revagade, N., and Hilborn, J. (2012). In vitro degradation of dry-jet-wet spun poly(lactic acid) monofilament and knitted scaffold. J. Appl. Polym. Sci. 103, 2006-2012. doi: 10.1002/app.25241

Hajba, S., Czigany, T., and Tabi, T. (2015). Development of cellulose-reinforced poly(lactic acid) (PLA) for engineering applications. Mater. Sci. Forum. 812, 59-64. doi: 10.4028/www.scientific.net/MSF.812.59

Hamad, K., Kaseem, M., Ayyoob, M., Joo, J., and Deri, F. (2018). Poly(lactic acid) blends: the future of green, light and tough. Prog. Polym. Sci. 85, 83-122. doi: 10.1016/j.progpolymsci.2018.07.001

Hassaini, L., Kaci, M., Touati, N., Pillin, I., Kervoelin, A., and Bruzaud, S. (2017). Valorization of olive husk flour as filler for biocomposites based on poly(3hydroxybutyrate-co-3-hydroxyvalerate):effects of silane treatment. Polym. Test. 59, 430-440. doi: 10.1016/j.polymertesting.2017.03.004

Hossain, K. M. Z., Ifty, H., Andrew, A., and Rudd, C. D. (2012). Physicochemical and mechanical properties of nanocomposites prepared using cellulose nanowhiskers and poly(lactic acid). J. Mater. Sci. 47, 2675-2686. doi: 10.1007/s10853-011-6093-4

Hossain, K. M. Z., Parsons, A. J., Rudd, C. D., Ahmed, I., and Thielemans, W. (2014). Mechanical, crystallization and moisture absorption properties of melt drawn poly(lactic acid) fibers. Eur. Polym. J. 53, 270-281. doi: 10.1016/j.eurpolymj.2014.02.001

Islam, M. S., Pickering, K. L., and Foreman, N. J. (2010). Influence of hygrothermal ageing on the physico-mechanical properties of alkali-treated industrial hemp fiber reinforced poly(lactic acid) composites. J. Polym. Env. 18, 696-704. doi: 10.1007/s10924-010-0225-9

Jewena, N., Miyanomae, R., Sasaki, M., and Mashimo, T. (2016). Hydrothermal decomposition of cellulose using strong gravitational field. J. Supercrit. Fluids 120, 379-383. doi: 10.1016/j.supflu.2016.05.034

Kummerer, T. W., Menz, J., and Schubert, T. (2011). Biodegradability of organic nanoparticles in the aqueous environment. Chemosphere 82, 1387-1392. doi: 10.1016/j.chemosphere.2010.11.069

Le Duigou, A., Davies, P., and Baley, C. (2009). Seawater ageing of flax/poly(lactic acid) biocomposites. Polym. Degrad. Stab. 94, 1151-1162. doi: 10.1016/j.polymdegradstab.2009.03.025

Ling, X., and Spruiell, J. E. (2006). Analysis of the complex thermal behavior of poly(L-lactic acid) film. ii. samples crystallized from the melt. J. Polym. Sci. B Polym. Phys. 44, 3378-3391. doi: 10.1002/polb.20987

Lins, L. C., Wianny, F., Livi, S., Hidalgo, I. A., Dehay, C., Duchet-Rumeau, J., et al. (2016). Development of bioresorbable hydrophilic-hydrophobic electrospun scaffolds for neural tissue engineering. Biomacromolecules 17, 3172-3187. doi: 10.1021/acs.biomac.6b00820

Loo, S. C. J., Ooi, C. P., Wee, S. H. E., and Boey, Y. C. F. (2005). Effect of isothermal annealing on the hydrolytic degradation rate of poly(lactide-coglycolide) (PLGA). Biomaterials 26, 2827-2833. doi: 10.1016/j.biomaterials.200 4.08 .031

Lorenzo, V., De Orden, M. U., and Martinez-Urreaga, J. (2016). Effect of different mechanical recycling processes on the hydrolytic degradation of poly(L-lactic acid). Polym. Degrad. Stab. 133, 339-348. doi: 10.1016/j.polymdegradstab.2016.09.018
Ma, M., and Zhou, W. (2015). Improving the hydrolysis resistance of poly(lactic acid) fiber by hydrophobic finishing. Ind. Eng. Chem. Res. 54, 2599-2605. doi: 10.1021/ie504814x

Maharana, T., Mohanty, B., and Negi, Y. S. (2009). Melt-solid polycondensation of lactic acid and its biodegradability. Prog. Polym. Sci. 34, 99-124. doi: 10.1016/j.progpolymsci.2008.10.001

Mangin, R., Vahabi, H., Sonnier, R., Chivas-Joly, C., Lopez-Cuesta, J.-M., and Cochez, M. (2018). Improving the resistance to hydrothermal ageing of flameretarded PLA by incorporating miscible PMMA. Polym. Degrad. Stab. 155, 52-66. doi: 10.1016/j.polymdegradstab.2018.07.008

Milanovic, J., Kostic, M., Milanovic, P., and Skundric, P. (2012). Influence of TEMPO-Mediated oxidation on properties of hemp fibers. Ind. Eng. Chem. Res. 51, 9750-9759. doi: 10.1021/ie300713x

Mitchell, M. K., and Hirt, D. E. (2015). Degradation of PLA fibers at elevated temperature and humidity. Polym. Eng. Sci. 55, 1652-1660. doi: 10.1002/pen.24003

Mohammad, S., Kaffashi, B., Torabinejad, B., and Zamanian, A. (2016). In-vitro investigation and hydrolytic degradation of antibacterial nanocomposites based on PLLA/triclosan/nano-hydroxyapatite. Polymer 83, 101-110. doi: 10.1016/j.polymer.2015.12.015

Mokhena, T. C., Sefadi, J. S., Sadiku, E. R., John, M. J., Mochane, M. J., and Mtibe, A. (2018). Thermoplastic processing of PLA/cellulose nanomaterials composites. Polymers 10:1363. doi: 10.3390/polym10121363

Mortaigne, B. (2005). Vieillissement des Composites-Mécanismes et-Méthodologie d'Etude. Techniques de l'Ingénieur. AM 5320.

Murariu, M., Dechief, A.-L., Paint, Y., Peeterbroeck, S., Bonnaud, L., and Dubois, P. (2012). Polylactide (PLA)-halloysite nanocomposites : production, morphology and key-properties. J. Polym. Env. 20, 932-943. doi: 10.1007/s10924-012-0488-4

Ndazi, B. S., and Karlsson, S. (2011). Characterization of hydrolytic degradation of poly(lactic acid)/rice hulls composites in water at different temperatures. Exp. Polym. Lett. 5, 119-131. doi: 10.3144/expresspolymlett.2011.13

Pan, F. J. L., Shen, Z., Wu, L., Zhang, Y., and Zhou, X. (2010). Hydrothermal production of formic and acetic acids from syringol. Appl. Phys. Eng. 11, 613-618. doi: 10.1631/jzus.A1000043

Persson, M., and Mikael, S. C. (2013). The effect of process variables on the properties of melt-spun poly(lactic acid) fibres for potential use as scaffold matrix materials. J. Mater. Sci. 48, 3055-3066. doi: 10.1007/s10853-012-7022-x

Pinese, C., Gagnieu, C., Nottelet, B., Rondot-Couzin, C., Hunger, S., Coudane, J., et al. (2016). In vivo evaluation of hybrid patches composed of PLA based copolymers and collagen/chondroitin sulfate for ligament tissue regeneration. J. Biomed. Mater. Res. Part B Appl. Biomater. 3, 1-11. doi: 10.1002/jbm.b.33712 Rahman, M. M., Afrin, S., Haque, P., Islam, M., Islam, M. S., and Gafur, Md. A. (2014). Preparation and characterization of jute cellulose crystals-reinforced poly(lactic acid) biocomposite for biomedical applications. Int. J. Chem. Eng. 2014:842147. doi: 10.1155/2014/842147

Remili, C., Kaci, M., Kachbi, S., Bruzaud, S., and Grohens, Y. (2009). Photooxidation of polystyrene/clay nanocomposites under accelerated UV exposure : effect on the structure and molecular weight. J. Appl. Polym. Sci. 112, 2868-2875. doi: 10.1002/app.29806

Ruiz, A., Rodrı, R. M., Fernandes, B. D., Vicente, A., and Teixeira, A. (2013). Hydrothermal processing as an alternative for upgrading agriculture residues and marine biomass according to the biorefinery concept: A review. Renew. Sustain. Energy Rev. 21, 35-51. doi: 10.1016/j.rser.2012.11.069

Santonja-Blasco, L., Ribes-Greus, A., and Alamo, R. G. (2013). Comparative thermal, biological and photodegradation kinetics of polylactide and effect on crystallization rates. Polym. Degrad. Stab. 98, 771-784. doi: $10.1016 /$ j.polymdegradstab.2012.12.012

Shieh, Y., and Liu, G. (2007). Temperature-modulated differential scanning calorimetry studies on the origin of double melting peaks in isothermally meltcrystallized poly(L-lactic acid). J. Polym. Sci. Part B Polym. Phys. 45, 466-474. doi: 10.1002/polb.21056

Stloukal, P., Jandikova, G., Koutny, M., and Sedla, V. (2016). Carbodiimide additive to control hydrolytic stability and biodegradability of PLA. Polym. Test. 54, 19-28. doi: 10.1016/j.polymertesting.2016.06.007

Sullivan, E. M., Moon, R. J., and Kalaitzidou, K. (2015). Processing and characterization of cellulose nanocrystals/poly(lactic acid) nanocomposite films. Materials 8, 8106-8116. doi: 10.3390/ma8125447 
Sun, Z., Zhang, L., Liang, D., Xiao, W., and Lin, J. (2017). Mechanical and thermal properties of PLA biocompositesreinforced by coir fibers. Int. J. Polym. Sci. 2017:2178329. doi: 10.1155/2017/2178329

Vilaplana, F., Strömberg, E., and Karlsson, S. (2010). Environmental and resource aspects of sustainable biocomposites. Polym. Degrad. Stab. 95, 2147-2161. doi: 10.1016/j.polymdegradstab.2010.07.016

Wang, T., and Drzal, L. T. (2012). Cellulose nanofiber-reinforced poly(lactic acid) composites prepared by a water-based approach. ACS Appl. Mater. Interfaces. 4, 5079-5085. doi: 10.1021/am301438g

$\mathrm{Wu}$, C.-S. (2009). Renewable resource-based composites of recycled natural fibers and maleated polylactide bioplastic: characterization and biodegradability. Polym. Degrad. Stab. 94, 1076-1084. doi: 10.1016/j.polymdegradstab.2009.04.002

Xian, X., Wang, X., Zhu, Y., Guo, Y., and Tian, Y. (2018). Effects of MCC content on the structure and performance of PLA/MCC biocomposites. J. Polym. Env. 26, 3484-3492. doi: 10.1007/s10924-018-1226-3

Yang, W., Fortunati, E., Dominici, F., Giovanale, G., Mazzaglia, A., Balestra, G. M., et al. (2016). Effect of cellulose and lignin on disintegration, antimicrobial and antioxidant properties of PLA active film. Int. J. Biol. Macromol. 89, 360-368. doi: 10.1016/j.ijbiomac.2016.04.068

Yew, G. H., Yusof, A. M. M., Mohd Ishak, Z. A., and Ishiaku, U. S. (2005). Water absorption and enzymatic degradation of poly(lactic acid)/rice starch composites. Polym. Degrad. Stab. 90, 488-500. doi: $10.1016 /$ j.polymdegradstab.2005.04.006
Yu, T., Sun, F., Lu, M., and Li, Y. (2018). Water absorption and hygrothermal aging behavior of short ramie fiber reinforced poly(lactic acid) composites. Polym. Compos. 39, 1098-1104. doi: 10.1002/pc.24038

Yuan, X., Mak, F. T., and Yao, K. (2002). In vitro degradation of poly(L-lactic acid) fibers in phosphate buffered saline. J. Appl. Polym. Sci. 85, 936-943. doi: 10.1002/app.10490

Zhang, X., Espiritu, M., Bilyk, A., and Kurniawan, L. (2008). Morphological behaviour of poly(lactic acid) during hydrolytic degradation. Polym. Degrad. Stab. 93, 1964-1970. doi: 10.1016/j.polymdegradstab.2008.06.007

Zhou, Q., and Xanthos, M. (2008). Nanoclay and crystallinity effects on the hydrolytic degradation of polylactides. Polym. Degrad. Stab. 93, 1450-1459. doi: 10.1016/j.polymdegradstab.2008.05.014

Conflict of Interest: The authors declare that the research was conducted in the absence of any commercial or financial relationships that could be construed as a potential conflict of interest.

Copyright (c) 2019 Aouat, Kaci, Lopez-Cuesta and Devaux. This is an open-access article distributed under the terms of the Creative Commons Attribution License (CC $B Y)$. The use, distribution or reproduction in other forums is permitted, provided the original author(s) and the copyright owner(s) are credited and that the original publication in this journal is cited, in accordance with accepted academic practice. No use, distribution or reproduction is permitted which does not comply with these terms. 